\title{
Receptors in the Induction of the Plant Innate Immunity
}

\author{
Tian-Ying Yu, ${ }^{\dagger}$ Meng-Kun Sun, and Li-Kun Liang \\ College of Life Sciences, Yantai University, Yantai 264005, China
}

Accepted 28 January 2021.

Plants adjust amplitude and duration of immune responses via different strategies to maintain growth, development, and resistance to pathogens. Pathogen-associated molecular pattern (PAMP)-triggered immunity (PTI) and effector-triggered immunity (ETI) play vital roles. Pattern recognition receptors, comprising a large number of receptor-like protein kinases and receptor-like proteins, recognize related ligands and trigger immunity. PTI is the first layer of the innate immune system, and it recognizes PAMPs at the plasma membrane to prevent infection. However, pathogens exploit effector proteins to bypass or directly inhibit the PTI immune pathway. Consistently, plants have evolved intracellular nucleotidebinding domain and leucine-rich repeat-containing proteins to detect pathogenic effectors and trigger a hypersensitive response to activate ETI. PTI and ETI work together to protect plants from infection by viruses and other pathogens. Diverse receptors and the corresponding ligands, especially several pairs of well-studied receptors and ligands in PTI immunity, are reviewed to illustrate the dynamic process of PTI response here.

Keywords: damage-associated molecular patterns (DAMPs), defense signaling pathways, PAMP-triggered immunity (PTI), pathogenassociated molecular patterns (PAMPs), pattern recognition receptors (PRRs), plant responses to pathogens, receptor-like protein kinases (RLKs), receptor-like proteins (RLPs), resistance genes

Plants, unlike animals, lack specific immune cells or organs and depend entirely on the innate immunity of each cell to protect themselves from potential pathogenic microbes. The innate immunity plays an important role in almost the entire life cycle of plants. Plants possess a two-tiered immune system comprising pathogen-associated molecular pattern (PAMP)-triggered immunity (PTI) and effector-triggered immunity (ETI). In PTI, the microbe-associated molecular patterns (MAMPs) or PAMPs released from bacteria, fungi, oomycetes, and nematodes are recognized by pattern recognition receptors (PRRs) at the plasma membrane. In addition to MAMPs and PAMPs, PRRs recognize damage-associated molecular patterns (DAMPs), which are the

T.-Y. Yu and M.-K. Sun contributed equally to this work.

${ }^{\dagger}$ Corresponding author: T.-Y. Yu: tyyu@ytu.edu.cn

Funding: This work was supported by the National Natural Science Foundation of China (31871450).

The author(s) declare no conflict of interest. endogenous signals generated upon cellular disintegration (Boller and Felix 2009).

PTI can prevent plants from pathogen infection, however, pathogens employ coevolution to produce new virulent effectors to suppress PTI and establish efficient infection. To fight against these effectors, plants have evolved intracellular nucleotide-binding domain leucine-rich repeat (LRR) proteins (resistance [R] proteins) to recognize pathogen effectors (Alfano and Collmer 2004; Austin et al. 2002; Maekawa et al. 2011). Effector recognition by $\mathrm{R}$ proteins leads to a hypersensitive response, a type of localized cell death that inhibits pathogen invasion and activates ETI (Alfano and Collmer 2004; Austin et al. 2002; Maekawa et al. 2011). However, it is noteworthy that ETI and PTI share some downstream signaling networks.

Plant encodes a large number of receptor-like protein kinases (RLKs) and receptor-like proteins (RLPs). Plant PRRs are either RLKs, consisting of an ectodomain (ECD), a single-pass transmembrane domain (TM), and an intracellular kinase domain (KD); or RLPs, with the same overall structure but no KD (Shiu and Bleecker 2001; Song et al. 1995). Some RLKs have a short extracellular juxtamembrane domain and an intracellular juxtamembrane domain (iJM). The ECD contains the LRR domain, lysine motifs (LysM), a lectin domain, or an epidermal growth factor (EGF)-like domain that is responsible for direct perception of different ligands (Denoux et al. 2008; Tanaka et al. 2014; Wan et al. 2008). Investigation of chimeric receptor kinases by fusion of ECD and intracellular parts from different RLKs indicates that the specificity of ligand-binding is provided by ECD, while the specific initiation of cytoplasmic signaling cascades is mainly achieved by the output signal specificity of intracellular KD (Albert and Felix 2010; He et al. 2000; Wu et al. 2019). RLPs are likely associated with one or more RLKs to transmit intercellular signals into the cell, because there is no distinct signal domains in their short intracellular regions (Bojar et al. 2014; Wu and Zhou 2013; Yan et al. 2012).

There are approximately 600 genes that encode the RLK family members, accounting for $2.5 \%$ of the Arabidopsis genome (Shiu and Bleecker 2001, 2003). RLKs play important roles in various physiological processes, specifically in perceiving diverse extracellular signals from PAMP, DAMP, and environmental stress. Ligand perception causes changes in conformation and activity of the cytoplasmic KD in receptor. Dimerization or oligomerization of RLKs is crucial for their activation. After receptor activation, activity of cytoplasmic signaling cascades is regulated by the phosphorylated RLKs, and subsequently results in the final signaling output. Instead of being isolated, the signal transduction pathways form an intricate network. Thus, a larger signaling network of physiological and biochemical responses regulated by certain pivotal proteins can be integrated in plants.

RLKs are categorized into different subfamilies in accordance with their extracellular domains. It has been clearly demonstrated that LRR-RLKs, LysM-RLKs, lectin-RLKs, and EGF-like RLKs 
contribute to plant growth and defense. One of the largest RLK families comprise LRR-RLKs, which play major roles in communication between cells and the external environment, as well as microbe sensing, plant growth, cell expansion, stomata development, stem cell maintenance, hormonal signals, and immune responses (Denoux et al. 2008; Tanaka et al. 2014; Wan et al. 2008). The LRR-RLKs FLAGELLIN-SENSITIVE 2 (FLS2), elongation factor Tu (EF-Tu) RECEPTOR (EFR), and plant elicitor peptide (PEP) RECEPTOR (PEPR1/PEPR2) detect bacterial flagella (22-amino acid peptide of flagellin, flg22), EF-Tu, and endogenous PEPs, respectively (Gómez-Gómez and Boller 2000; Z. Liu et al. 2013; Zipfel et al. 2006). Xanthomonas resistance 21 (XA21) is a receptor for microbial sulfated peptide RaxX (required for activation of XA21-mediated immunity to Xanthomonas oryzae pv. oryzae) (Luu et al. 2019; Song et al. 1995). The phytosulfokine (PSK) receptor 1 (PSKR1) and the plant peptide sulfated tyrosine 1 (PSY1) receptor 1 (PSY1R) are involved in PTI signaling by recognizing their own ligands (Igarashi et al. 2012; Mosher et al. 2013). ERECTA (ER) and suppressor of brassinosteroid (BR) receptor-insensitive 1 (BRI1)-associated kinase 1 (BAK1)-interacting receptor kinase 1 (BIR1)-1 (SOBIR1) act as key players in specification of organs and RLP-triggered defense, respectively (Larkan et al. 2015; Shpak et al. 2003, 2005; Torii et al. 1996; van der Burgh et al. 2019).

In addition to LRR-RLKs, the LysM RLK chitin elicitor receptor kinase 1 (CERK1), the lectin-RLKs doesn't respond to nucleotides (DORN1) and lipooligosaccharide-specific reduced elicitation (LORE), and EGF-like RLK cell-wall-associated kinase (WAK1) initiate downstream signal transduction in plant defense (De Lorenzo et al. 2011; Denoux et al. 2008; Kohorn et al. 2009; Kutschera et al. 2019; Petutschnig et al. 2010; Tanaka et al. 2014). Malectin-like receptor kinase FERONIA (FER) and impaired oomycete susceptibility 1 (IOS1) are also efficient PRRs for identification of elicitors in plants (Li et al. 2015; Yeh et al. 2016; Yu and Assmann 2018). Strikingly, double-stranded RNA is sensed by unknown PRRs that are associated with somatic embryogenesis receptor kinase 1 (AtSERK1) and induce PTI in Arabidopsis (Niehl et al. 2016). These RLKs and RLPs are shown in Table 1.

Recognition of PAMPs or DAMPs by RLKs induces homo- or heterooligomerization of RLKs and RLPs, and triggers receptorlike cytoplasmic kinases (RLCKs) to switch on a common set of signaling and intracellular defense responses. There are $46 \mathrm{mem}-$ bers such as Botrytis-induced kinase 1 (BIK1), BR-signaling kinase 1 (BSK1) (Boller and Felix 2009; Lu et al. 2010; J. Wang et al. 2017), and PTI-COMPROMISED RLCK 1 (PCRK1) (Sreekanta et al. 2015) in RLCK subfamily VII of Arabidopsis.

An overview of well-characterized PRRs (either RLKs or RLPs), the mode of perception at the plasma membrane, and the increasing apparent diversity and conformity of PRRs and corresponding ligands are presented in this review. In particular, we focus on the best-studied receptor-ligand pair, FLS2-flg22 and EFRelf18, to elucidate the molecular mechanism of PTI responses.

\section{RLKS (RLPS) RECOGNIZE MAMPs/PAMPs}

\section{LRR-RLK (RLP) receptors.}

FLS2. FLS2 belongs to the LRR-RLK XII family in Arabidopsis and consists of 1,173 amino acids (Gómez-Gómez and Boller 2000). FLS2 is a well-studied PRR that recognizes the conserved flg22 at the plasma membrane (Chinchilla et al. 2006; Zipfel et al. 2004). The FLS2 extracellular domain comprises 28 LRRs, including an LRR N-terminal domain (LRRNT) and an LRR C-terminal domain (LRRCT), and is flanked by domains with double-cysteine motifs (Boller and Felix 2009). LRRNT is highly conserved and contains a glycosylation site. A consensus residue sequence LXXLXLXXN ( $\mathrm{X}$ is for any amino acid and $\mathrm{L}$ is for leucine or other hydrophobic amino acid residues) that is essential for protein-protein interaction is usually found in every LRR domain. The TM isolates the extracellular domain from the intracellular domain with serine/threonine (Ser/Thr) protein kinase activity (Robatzek and Wirthmueller 2013). A proline-glutamic acidserine-threonine-like motif (PEST:amino acid residues) is located within the cytoplasmic part of FLS2, and it is modified through monoubiquitination and participates in ligand-induced FLS2 endocytosis (Robatzek et al. 2006). There is an ATP-binding site lacking a conserved GxGxxG motif in the intracellular KD of FLS2, and no conserved arginine-aspartic acid (RD) motif was present in the activation loop of FLS2 (Dardick and Ronald 2006). Therefore, FLS2 kinase belongs to the non-RD kinases, with the RD motif replaced by a CD motif (cysteine-aspartic acid) in catalytic loop.

EFR. The structure of EFR resembles that of FLS2, and EFR also belongs to the LRR-RLK XII family in Arabidopsis. It consists of 1,031 amino acids (Zipfel et al. 2006). The EFR plays a role as a PRR to recognize EF-Tu, one of the most abundant and conserved proteins in bacteria. EF-Tu plays a crucial role in bacterial protein biosynthesis (Zipfel et al. 2006). Peptides representing the most highly conserved part of the $\mathrm{N}$ acetylated 18 and 26 amino-acid epitope of EF-Tu, called elf18 and elf26, are critical for binding to EFR (Kunze et al. 2004). By contrast, the shorter peptide elf12 acts as a specific antagonist of elf18 instead of a PAMP (Kunze et al. 2004). EF-Tu perception is limited to certain species in the Brassicaceae family, and members of other plant groups are unlikely to carry homology to EFR (Zipfel et al. 2006). EF-Tu cannot be sensed in $\mathrm{Ni}$ cotiana benthamiana. However, EF-Tu recognition occurs with transiently expressed receptor kinase EFR in $N$. benthamiana (Zipfel et al. 2006).

The EFR has 21 LRRs flanked by the conserved LRRNT and LRRCT in ECD. The C-terminal region of EFR is highly conserved and possesses the structural elements of a Ser/Thr protein kinase. It indicates that EFR is similar to FLS2 and belongs to the non-RD kinases. The N-terminus of the EFR kinase contains a hydrophobic signal peptide that guides protein to be synthesized on ER and integrated in membrane.

XA21. XA21 from Oryza longistaminata is a member of the LRR-RLK XII family that recognizes a highly conserved protein secreted from $X$. oryzae pv. oryzae, a sulfated microbial peptide termed RaxX (Luu et al. 2019). XA21 shares similarities with the EFR and FLS2 receptors of Arabidopsis, for it possesses similar structures in the LRR-containing ECD and a non-RD intracellular kinase, and mediates immune-recognition events (Dardick and Ronald 2006; Pruitt et al. 2015; Song et al. 1995). In addition, just like EFR, the functional XA21 occurs only in certain rice cultivars (Lacombe et al. 2010; Wang et al. 1998).

XA21 is maintained in an inactive status by association with an ATPase XA21-binding protein24 (XB24) (Chen et al. 2010) when the plant is free from pathogens. Upon challenge from $X$. oryzae pv. oryzae, XA21 is disassociated from XB24 and further initiates an XA21-mediated innate immune response (Ronald 1997). XA21 phosphorylates E3 ubiquitin ligase (XA21-binding protein 3 [XB3]) (Wang et al. 2006) and, subsequently, activates a mitogen-activated protein kinase (MAPK) cascade. Furthermore, XA21-binding protein XB15, a protein phosphatase $2 \mathrm{C}$, negatively regulates the XA21-mediated innate immune response through dephosphorylation events (Park et al. 2008). Orthologous proteins XA3 and XA26 are similar to XA21 in structure. XA3 and XA26 associate with the LRR-RLK OsSERK2 and confer resistance to $X$. oryzae pv. oryzae strains via an as-yet-unknown mechanism (Cao et al. 2007; X. Chen et al. 2014; Sun et al. 2004; Wang et al. 2006).

ECD and endo-domain exchanges between XA21 of $O$. sativa and EFR of Arabidopsis were implemented by cell-surface receptor-domain swap studies recently. Full resistance to $X$. oryzae pv. oryzae was sufficiently conferred by the combination of 
ECD of XA21 with the intracellular EFR domain (Thomas et al. 2018). When the ECD of EFR was fused to the KD of XA21, the resulting chimeric receptor perceived elf18 and was enabled to trigger PTI response in Arabidopsis, in a way similar to EFRtriggered signaling (Schwessinger et al. 2015).

Other receptors for flagellin and EF-Tu.

A 28-amino-acid epitope called flgII-28 in tomato and several other solanaceous plants is perceived by FLAGELLIN-SENSITIVE 3 (FLS3) (Cai et al. 2011). FLS3 is a member of LRRRLK XII and acts as a receptor to trigger immunity in an as-yet-unknown manner (Hind et al. 2016). It is demonstrated that a defense-related reaction is promoted by flgII 28 -stimulated cytosolic $\mathrm{Ca}^{2+}$ increase in potato (Moroz and Tanaka 2020). There is evidence that flgII-28 is not directly recognized by FLS2 (Clarke et al. 2013). Interestingly, in Arabidopsis, flgII-28 alleles affect bacterial virulence in an FLS2-dependent manner, although the mechanism remains unclear (Moroz and Tanaka 2020). Likewise, C-terminal D2 domain (CD2)-1, an epitope of Acidovorax avenae flagellin, is perceived by an unknown receptor in rice (Fliegmann and Felix 2016).
EFa50, an EF-Tu middle region including Lys176 to Gly225, is reported to function as a PAMP in rice (Furukawa et al. 2014). EFa50 induces hydrogen peroxide $\left(\mathrm{H}_{2} \mathrm{O}_{2}\right)$ generation and callose deposition, and also triggers resistance to bacteria via an unknown PRR in rice. Therefore, it is significant to study and characterize the enigmatic receptor of $\mathrm{EFa} 50$.

Xanthine/uracil permease sensing 1.

Recently, Mott et al. (2016) used genomic screens to identify a new LRR-RLK XII receptor, xanthine/uracil permease sensing 1 (XPS1). XPS1 directly recognizes xup25 (xanthine/uracil permease peptide 25) (eliciting peptides from phytopathogenic bacterium $P$. syringae) that derived from a protein of the xanthine/ uracil permease family, and activates its immune defense (Mott et al. 2016). However, no coreceptor of plant LRR-RLK XPS1 has been discovered thus far.

Cold shock protein receptor.

LRR-RLK cold shock protein receptor (CORE) can perceive the conserved intracellular domains of the bacterial cold shock proteins (CSPs) csp15 and csp22, and confer csp22 responsiveness and increase resistance to Pseudomonas syringae in Arabidopsis

Table 1. Receptor-like protein kinases (RLKs) and receptor-like proteins (RLPs) involved in pattern recognition receptor-triggered immunity ${ }^{\mathrm{a}}$

\begin{tabular}{|c|c|c|c|}
\hline Name & Family & Ligands & References \\
\hline \multicolumn{4}{|l|}{ MAMP signal } \\
\hline \multicolumn{4}{|l|}{ LRR-RLK } \\
\hline FLS2 & XII & Flagellin/flg22/CLV3p & Hayashi et al. 2001; Robatzek and Wirthmueller 2013 \\
\hline EFR & XII & EF-Tu/elf18 & Albert and Felix 2010; Shiu and Bleecker 2003 \\
\hline XA21 & XII & $\operatorname{RaxX}$ & Luu et al. 2019; Song et al. 1995 \\
\hline FLS3 & XII & flgII-28 & Clarke and Vinatzer 2017; Hind et al. 2016 \\
\hline XPS1 & $\mathrm{XII}$ & xup25 & Mott et al. 2016 \\
\hline \multicolumn{4}{|l|}{ LRR-RP } \\
\hline RLP23 & - & NLPs & Albert et al. 2015 \\
\hline RLP30 & - & SCFE1 & Zhang et al. 2013 \\
\hline Ve1 & - & Ave1 & de Jonge et al. 2012 \\
\hline $\mathrm{cf}-2$ & - & Avr2 & Luderer et al. 2002 \\
\hline cf-4 & - & Avr4 & Joosten et al. 1997 \\
\hline cf- 9 & - & Avr9 & Jones et al. 1994; Van den Ackerveken et al. 1992 \\
\hline CORE & - & $\operatorname{csp} 15$ & Saur et al. 2016; L. Wang et al. 2016 \\
\hline ELR & - & elicitin & Du et al. 2015; Peng et al. 2015 \\
\hline \multicolumn{4}{|l|}{ LysM-RLK } \\
\hline CERK1 & LysM & Chitin & Radutoiu et al. 2003; Wan et al. 2008 \\
\hline EPR3 & LysM & EPS & Kawaharada et al. 2015, 2017 \\
\hline LYK5 & LysM & Chitin & Cao et al. 2014; Wan et al. 2012 \\
\hline LYK4 & LysM & Chitin & Xue et al. 2019 \\
\hline \multicolumn{4}{|l|}{ LysM-RP } \\
\hline AtLYM1 & LysM & Chitin & Willmann et al. 2011 \\
\hline AtLYM3 & LysM & Chitin & Willmann et al. 2011 \\
\hline CEBiP & LysM & Chitin & Desaki et al. 2018b; Hayafune et al. 2014 \\
\hline LYM2 & LysM & Chitin & Shinya et al. 2012 \\
\hline OsLYP4/6 & LysM & Chitin & Kouzai et al. 2014; Liu et al. 2012 \\
\hline \multicolumn{4}{|l|}{ Lectin-RLK } \\
\hline LORE & Lectin & LPSs & Ranf et al. 2015 \\
\hline \multicolumn{4}{|l|}{ DAMP signal } \\
\hline \multicolumn{4}{|l|}{ RLK } \\
\hline FER & Malectin & RALFs & Guo et al. 2018; Stegmann et al. 2017; Yu and Assmann 2018 \\
\hline DORN1 & Lectin & eATP & Choi et al. 2014 \\
\hline LecRK-I.8 & Lectin & eNAD & C. Wang et al. 2017 \\
\hline RLK7 & XI & PIP1/PIP2 & Hou et al. 2014 \\
\hline PEPR1 & XI & PEP1/2/3/4/5/6/7/8 & Bartels et al. 2013; Huffaker et al. 2006; Lori et al. 2015 \\
\hline PEPR2 & XI & $\mathrm{PEP} 1 / 2$ & Bartels et al. 2013; Huffaker et al. 2006 \\
\hline PSKR1 & $\mathrm{X}$ & PSKs & Kaufmann et al. 2017; Wang et al. 2015 \\
\hline PSY1R & $\mathrm{X}$ & PSY1 & Amano et al. 2007 \\
\hline \multicolumn{4}{|l|}{ EGF-like RLK } \\
\hline WAKs & - & OGs & Denoux et al. 2008 \\
\hline
\end{tabular}

\footnotetext{
${ }^{\mathrm{a}} \mathrm{MAMP}=$ mitogen-activated protein kinase, $\mathrm{LRR}=$ leucine-rich repeat, $\mathrm{EFR}=\mathrm{EF}-\mathrm{Tu}$ receptor, EF-Tu $=$ elongation factor $\mathrm{Tu}, \mathrm{XA} 21=\mathrm{Xanthomonas}$ resistance 21, XPS = xanthine/uracil permease sensing, NLP = necrosis and ethylene-inducing peptide 1-like protein, SCFE $=$ Sclerotinia culture filtrate elicitor, $\mathrm{VE} 1=$ Verticillium $1, \mathrm{Avr}=$ avirulence, $\mathrm{CORE}=$ cold shock protein receptor, $\mathrm{ELR}=$ elicitin recognition $\mathrm{RLP}$ elicitin response, LysM $=$ lysine motif, $\mathrm{CERK}=$ chitin elicitor receptor kinase, $\mathrm{EPR}=$ exopolysaccharide receptor, $\mathrm{EPS}=$ exopolysaccharide, $\mathrm{CEBiP}=$ chitin oligosaccharide elicitor binding protein, LORE = lipooligosaccharide-specific reduced elicitation, LPS $=$ lipopolysaccharide, DAMP = damage-associated molecular pattern, FER $=$ FERONIA, RALF $=$ rapid alkalinization factor, DORN $=$ doesn't respond to nucleotides, eATP $=$ extracellular ATP, NAD $=$ nicotinamide adenine dinucleotide, $\mathrm{PIP}=$ plasma membrane intrinsic protein, $\mathrm{PEP}=$ plant elicitor peptide, $\mathrm{PEPR}=\mathrm{PEP}$ receptor, $\mathrm{PSK}=$ phytosulfokine, $\mathrm{PSKR}=\mathrm{PSK}$ receptor, $\mathrm{PSY}=$ peptide sulfated tyrosine, $\mathrm{EGF}=$ epidermal growth factor, and $\mathrm{WAK}=$ cell-wall-associated kinase
} 
(Felix and Boller 2002; L. Wang et al. 2016). CORE strongly resembles EFR and XA21, in which their ECD has 22 LRRs and is interrupted at LRR11 with a 6-amino-acid island domain (L. Wang et al. 2016). A csp22 peptide from Ralstonia solanacearum is perceived and results in robust immune responses in tomato, $N$. benthamiana, and tobacco but not in Arabidopsis (Wei et al. 2018). N. benthamiana RLP required for csp22 responsiveness (NbCSPR), an LRR-RLP, confers response to csp22 and recruits BAK1 and SOBIR1 (Saur et al. 2016).

LRR-RLPs receptors and its coreceptor SOBIR.

Studies on an LRR-RLK, SOBIR1/EVERSHED, reveal that SOBIR1 functions as a pivot in RLP-mediated immune defense (Gao et al. 2009; Liebrand et al. 2013). SOBIR1 has an ECD with five LRRs, a transmembrane region with conserved GxxxG motifs, and an intracellular $\mathrm{KD}$ (Bi et al. 2016). It is the GxxxG motif, not the LRR domain in the ECD or the intracellular kinase, which is required for interaction with different RLPs (Bi et al. 2016; Hohmann and Hothorn 2019). SOBIR1 is a typical RD kinase (Bi et al. 2016).

It was clearly shown in initial studies that SOBIR 1 constitutively interacts with LRR-RLP Cladosporium fulvum proteins (Cf proteins) of tomato, conferring resistance to specific races of avirulence (Avr)4 and Avr9 secreted by the fungal pathogen $C$. fulvum. After ligand recognition, conformational alteration of the Cf proteins Cf-4 or Cf-9 leads to an association with SOBIR1 (Liebrand et al. 2013). BAK1 is further specifically recruited to the Cf protein/SOBIR1 complex, initiating trans- or autophosphorylation between SOBIR1 and BAK1 (Liebrand et al. 2013). The activated receptor complexes subsequently promote downstream cytoplasmic signaling elements and initiate RLPtriggered immunity in tomato (Liebrand et al. 2013, 2014).

Similar to Cf proteins, Verticillium 1 (Ve1) protein recognizes the fungal peptide Ave1 secreted by Verticillium dahliae, and associates with SOBIR1 in tomato (Castroverde et al. 2016; Fradin et al. 2011; Kawchuk et al. 2001). Ethylene (ET)-inducing xylanase (EIX) is recognized via the LRR-RLPs EIX2 and EIX1 in tomato and N. tabacum. Moreover, the receptor of EIX interacts with SOBIR1 (Ron and Avni 2004; Sharon et al. 1992). Sclerotinia culture filtrate elicitor 1 (SCFE1) from the necrotrophic fungal pathogen Sclerotinia sclerotiorum is recognized by RLP30. RLP30, together with SOBIR1, recruits BAK1 in a ligand-dependent manner (Zhang et al. 2013).

Furthermore, assays are extended to studies of other RLPs and SOBIR1. RLP23 recognizes a conserved 20-amino-acid fragment found in most necrosis and ET-inducing peptide 1-like proteins (NLPs) (NLP20) from bacterial, fungal, and oomycete necrosis (Albert et al. 2015; Wan et al. 2019). Increasing evidence indicates that an RLP23-SOBIR1-BAK1 complex triggers NLP-mediated immunity (Albert et al. 2015). Similar to Cf proteins, RLP23 forms a constitutive and ligand-independent heterooligomer with SOBIR1 and recruits BAK1 into a tripartite complex upon ligand binding. Thereby, SOBIR1 and BAK1 auto- or transphosphorylate and, subsequently, activate downstream defense signaling (Albert et al. 2019; van der Burgh et al. 2019).

The LRR-RLP RLP1 (also termed ReMAX, receptor of eMax) with specificity for eMax of xanthomonads forms constitutive dimers with LRR-RLK SOBIR1 (Jehle et al. 2013). Responsiveness to botrytis polygalacturonases1 (RBPG1, also named RLP42) recognizes fungal polygalacturonases (PGs) and constitutively associates with RLK SOBIR1 as a signaling adapter. The RLP42-SOBIR1 complex interacts with a SERKlike RLK other than BAK1 (Zhang et al. 2014).

Elicitin recognition RLP elicitin response (ELR) is composed of 1,094 amino acids, including extracellular 36 LRR domains, a transmembrane domain, and a short cytoplasmic tail (Du et al. 2015). ELR perceives elicitin and functions in complex ELR-
SOBIR1-SERK3 to mediate broad-spectrum resistance to several Phytophthora spp. (Domazakis et al. 2018; Du et al. 2015; Peng et al. 2015).

\section{LysM-RLKs.}

CERK1, chitin oligosaccharide elicitor binding protein (LYSIN MOTIF DOMAIN-CONTAINING GLYCOSYLPHOSPHATIDYLINOSITOL-ANCHORED PROTEIN), LysM proteins, and LysM kinases. Chitin is the main component of the fungal cell wall, and serves as a classical PAMP, recognized by LysM-containing RLK 1 (LYK1)/CERK1 (Miya et al. 2007; Shimizu et al. 2010; Wan et al. 2008). CERK1, also known as LysM-RLK1, has an ECD comprising three LysMs that possibly combine with chitin and an intracellular Ser/Thr KD (Wan et al. 2008). LysM-type proteins generally communicate with chitin-related molecules and nodulation factors for initiation of root nodulation (Radutoiu et al. 2003).

According to the "sandwich" model, following chitin treatment in rice, LysM-RLP chitin oligosaccharide elicitor binding protein $(\mathrm{CEBiP})$ connects with OsCERK1 to form a sandwichtype receptor complex, in which two ECDs of CEBiP combine with chitin, with one on each side (Desaki et al. 2018a; Hayafune et al. 2014). The RLP CEBiP contains three LysM domains and a glycosylphosphatidylinositol tail anchored to the plasma membrane (Kaku et al. 2006). However, it is unclear why shorter chitin oligomers (4 to 5 GlcNAc residues) do not induce CERK1 homodimerization (Liu et al. 2012). The "sliding mode" suggests that two CEBiP-ECDs form a long but offset chitin-binding groove, and slide along the chitin chain by alternating $\mathrm{N}$-acetyl groups from opposite sides for optimum interaction (Gubaeva et al. 2018). Gubaeva et al. (2018) proposed a "slipped sandwich" model differing from the sliding mode by the presence of the shared middle GlcNAc unit of chitin. In addition, the LysM-RLPs LysM protein 4 (OsLYP4) and OsLYP6 also contribute to OsCERK1-mediated defense in rice (B. Liu et al. 2013).

Different from the mechanism of chitin perception in rice, AtCERK1 mediates homodimerization and phosphorylation through directly binding octamers of chitin in Arabidopsis. The LysM-containing receptor kinase LYK5 exhibits much higher chitin-binding affinity than OsCERK1. LYK5 and the related LysM-RK LYK4 link to AtCERK1, forming an intact complex upon chitin perception (Cao et al. 2014; Wan et al. 2012). LYK4 functions as a scaffold protein or acts as a coreceptor for LYK5, which promotes chitin-triggered signaling in Arabidopsis (Xue et al. 2019). However, it is unclear how the endocytosis of LYK5 is accompanied with this process. It is pertinent to mention that AtCERK1 appears to phosphorylate LYK5 to induce endocytosis of LYK5 upon chitin perception (Cao et al. 2014; Erwig et al. 2017).

LYSIN MOTIF DOMAIN-CONTAINING GLYCOSYLPHOSPHATIDYLINOSITOL-ANCHORED PROTEIN 2 (LYM2), an ortholog of AtCEBiP, also chemically binds chitin and is not required for AtCERK1-mediated chitin signaling (Faulkner et al. 2013; Shinya et al. 2012). LYM2 protein contributes to chitin-induced plasmodesmata closure, thus offering disease resistance (Narusaka et al. 2013). A novel plant U-box E3 ubiquitin ligase, PUB4, was recently found to be involved in regulation of chitin signaling as an interactor of CERK1 in Arabidopsis (Desaki et al. 2019).

However, the perception of bacterial peptidoglycan (PGN) of CERK1 defines another mechanism. PGNs are typical components of bacterial cell walls. Fragments with alternating $\beta(1,4)$ linked $\mathrm{N}$-acetylmuramic acid and $\mathrm{N}$-acetylglucosamine glycan are released during infection (Miyata et al. 2014). Two orthologs of LysM-RLP CEBiP, AtLYM1 and AtLYM3, are involved in pathogen resistance via the CERK1-mediated immune pathway 
in Arabidopsis (Willmann et al. 2011). AtLYM1 and AtLYM3 recognize elicitors through LysM-domain-containing proteins and act in a complex with CERK1. Two LysM-containing RLPs, LYP4 and LYP6, also serve as specific receptors for PGNs and form complexes with OsCERK1 in rice (Kouzai et al. 2014; B. Liu et al. 2013).

In contrast to rice and Arabidopsis, PGN induces a connection between AtCERK1 and its homologs LysM receptor kinase AvrPtoB tomato-interacting protein 9, Solanum lycopersicum LysM RLK (SILyk)11, SILyk12, and SILyk13 in tomato (Zeng et al. 2012). CERK1 might also contribute to lipopolysaccharide (LPS)-triggered signaling in rice (Desaki et al. 2018b).

Exopolysaccharide receptor 3. Exopolysaccharide receptor 3 (EPR3), an RLK containing three LysM motifs, perceives and distinguishes compatible and incompatible exopolysaccharides (EPSs) in Lotus japonicus (Kawaharada et al. 2015, 2017). EPR3 is essential to promote the mechanism of the intracellular cortical infection by controlling crack entry (Kawaharada et al. 2015, 2017).

\section{Lectin-RLKs.}

LORE. The lectin-RLK LORE (LPS-SPECIFIC REDUCED ELICITATION) is a bulb-type lectin S-domain-1 RLK and the PRR for bacterial LPSs (Ranf et al. 2015). LORE-mediated plant defense is restricted to the Brassicaceae family and cannot be detected in N. benthamiana, tomato, Hordeum vulgare, or rice (Ranf et al. 2015). There are biphasic reactive oxygen species (ROS) bursts in Arabidopsis, with an early, substantially weaker elevation of ROS and a second, long-lasting ROS burst; however, only the persistent ROS burst is induced by LPS (Shang-Guan et al. 2018). Although those findings provide evidence of LPS-activated LORE ROS production, the mechanism connecting LPS recognition and LORE-mediated signaling remains ambiguous. Recently, Kutschera et al. (2019) and Luo et al. (2020) found that medium-chain 3-hydroxy fatty acids take roles as a PAMP to be recognized and induces phosphorylation of LORE at tyrosine residue 600 (Y600). Phosphorylated LORE subsequently transphosphorylates the RLCK AvrPphBsusceptible-like protein (PBL)34 and its close paralogs, PBL35 and PBL36, and, therefore, activates downstream immune signaling.

\section{Malectin-like-RLKs.}

IOS1. Malectin-like LRR-RLK IOS1 functions in plant PTI signaling. IOS1 is grouped in LRR-RLK I, because it is composed of two LRR motifs, a TM and an extracellular malectinlike domain (Hok et al. 2011). IOS1 forms complexes with EFR, FLS2, and CERK1 in PTI responses (C. W. Chen et al. 2014; Yeh et al. 2016). Once stimulated by elicitors, IOS1 might contribute to the formation of a new complex that integrates both PRRs and BAK1. Notably, IOS1 is required for ligand-induced PRR-BAK1 association but is not decisive for BIK1 phosphorylation (Yeh et al. 2016). In addition to promoting formation of PRR-BAK1 complex, IOS1 associates with BSK3, too (Yeh et al. 2016).

\section{RLKS (RLPS) RECOGNIZE DAMP}

\section{LRR-RLKs (RLPs).}

PEPRs. AtPEPR1 and AtPERP2, which belong to LRRRLK XI family in Arabidopsis, perceive DAMPs such as PEPs in cells (Huffaker et al. 2006; Krol et al. 2010; Pearce et al. 2008; Yamaguchi et al. 2006). PEPR1 shares a similar structure to EFR and FLS2, except that its extracellular domain consists of 27 LRRs (Yamaguchi et al. 2006). The primary function of AtPEPR1 and AtPEPR2 is to control PTI. AtPEPR1 perceives AtPep1 to AtPep8, whereas it seems that AtPEPR2 detects
AtPep1 and AtPep2 only (Bartels et al. 2013). As a homolog of PEPR1, PEPR2 shares amino acid identity of $64 \%$ and similarity of $76 \%$ to PEPR1. PEPs contain 23 amino acids derived from the C-terminal regions of their precursor proteins such as PROPEP1 (Huffaker et al. 2006; Yamaguchi et al. 2010). Moreover, it is suggested that AtPEPRs perceive ZmPep1 and SlPep1, and mediate PAMP-triggered defense by transient expression in $N$. benthamiana (Huffaker et al. 2011; Lori et al. 2015). The region of the last 15 amino acids in PEP1 shows similar activity to unmodified AtPEP1 (Lori et al. 2015). The extracellular Arg-XArg domain of PEPR interacts with a C-terminal Asn residue of PEP1 (Z. Liu et al. 2013; Tang et al. 2015).

The peprl and pepr2 mutants are less sensitive to PEPs but more sensitive to bacteria. Reduced expression of defense-related gene PDF1.2 and decreased ROS accumulation are reported in the mutants compared with wild-type plants (Flury et al. 2013; Krol et al. 2010; Ma et al. 2012). This suggests that PEPR1 and its close homolog PEPR2 activate defense-related genes for innate immune response.

As analogs to FLS2 and EFR, PEPR1 and PEPR2 heterodimerize with BAK1 upon ligand binding as well (Postel et al. 2010). Proline, glutamine, and histidine of AtPEP play crucial roles in this interaction (Pearce et al. 2008). PEPR1 directly phosphorylates BIK1 and the closely related PBL1 in a BAK1independent manner (Z. Liu et al. 2013).

Transcription factor WRKY33 regulates expression of PROPEP2 and PROPEP3 to enhance immune signaling via PEPPEPR recognition. WRKYs are activated by MAPKs after the MAPK cascading response, and WRKY33 directly binds to the W-box regions of the PROPEP2/PROPEP3 promoter to improve the gene expression (Logemann et al. 2013; Ross et al. 2014). In addition, jasmonic acid (JA) and salicylic acid (SA) increase transcription of PROPEP4, PROPEP5, and PROPEP6 in Arabidopsis (Huffaker and Ryan 2007). Transcription of the basal resistance-required PROPEP3 is likely enhanced by suppression of BAK1. PEPR-triggered signaling can maintain basal immunity when PTI is compromised; however, it remains unknown how BAK1 depletion is associated with PEPR mediated resistance (Yamada et al. 2016).

PEPR1/2 ortholog RLK 1. Tomato LRR-RLK PEPR1/2 ortholog RLK 1 (PORK1) regulates response to systemin in association with tomato protein kinase $1 \mathrm{~b}$, and takes an important role in the plant immune response (Xu et al. 2018). PORK1 shares structural and phylogenetic similarity with AtPEPR1 and AtPEPR2 proteins and causes resistance to Botrytis cinerea and Manduca sexta. However, neither production of ROS nor MAPK activation can be induced in PORK1 RNAi plants. Further study is required to unveil the function of PORK1 $(\mathrm{Xu}$ et al. 2018).

PSKR1 and PSY1R. PSK is a pentapeptide with disulfated tyrosine that originates from a nonfunctional precursor protein (Matsubayashi and Sakagami 1996). PSY1 has 18 amino acids. PSY1 is derived from another group of sulfated peptides and comprises a triarabinose sugar moiety anchored at one of two hydroxyl residues (Amano et al. 2007). PSKR1 and PSY1R are members of the Arabidopsis LRR-RLK X family and mediate the PSK and PSY1 Tyr-sulfated peptide signaling pathways, respectively (Igarashi et al. 2012; Mosher et al. 2013). PSKR1 and PSY1R are likely important for cellular dedifferentiation proliferation and plant immunity (Igarashi et al. 2012; Mosher et al. 2013).

After ligand binding, the phosphorylated PSY1R receptor activates proton pumps in plasma membrane and PSY1R, in turn, utilizes these proton pumps to propagate the signaling cascade (Fuglsang et al. 2014; Ladwig et al. 2015). The PSKR1 ECD perceives PSK ligand, resulting in dimerization of PSKR1 with the SERK1 binding partner (J. Wang et al. 2016). PSKR1 and 
PSY1R play multiple roles and integrate EFR and FLS2 signal crosstalk to modulate immunity (Igarashi et al. 2012; Mosher et al. 2013). It was reported that PSKR1 interacts with calmodulin $(\mathrm{CaM})$ to regulate kinase activity (Kaufmann et al. 2017).

RLK7. The class XI LRR-RLK RLK7 participates in detection of plasma membrane intrinsic protein (PIP) PIP1/PIP2, a synthetic 13-amino-acid peptide corresponding to the C-terminal part of precursors of PAMP-induced secreted peptides (prePIP1/ prePIP2). PIP1/PIP2 collaborates with the DAMP PEP1 to amplify flagellin-triggered immune responses or to mediate overlapping and distinct immune signaling responses (Hou et al. 2014).

\section{Lectin-RLKs.}

DORN1. Several lectin-RLKs are involved in plant disease resistance. The lectin-RLK DORN1 was the first plant purinergic receptor involved in plant immunity and required for resistance to the oomycete pathogens Phytophthora brassicae and $P$. infestans and the bacterial pathogen Pseudomonas syringae (Chen et al. 2017; Choi et al. 2014). Extracellular ATP is a potential agonist for DORN1, which limits microbial invasion by inducing stomatal closure in Arabidopsis (Chen et al. 2017). DORN1 is composed of an extracellular legume L-type lectin domain, a TM, and an intracellular Ser/Thr KD. ATP-triggered activation of the DORN1 kinase function induces cytosolic $\mathrm{Ca}^{2+}$ elevation and MAPK activation, which leads to phosphorylation of respiratory burst oxidase homolog D (AtRBOHD) and results in an ROS burst (Choi et al. 2014).

LecRK-I.8. Arabidopsis lectin receptor LecRK-I.8 is a cellsurface receptor that belongs to the lectin receptor kinase subfamily. LecRK-I.8 includes an extracellular legume L-type lectin domain and intracellular Ser/Thr kinase domain. LecRK-I.8 is identified to perceive the extracellular nicotinamide adenine dinucleotide $\left(\mathrm{NAD}^{+}\right)$and trigger immune response $(\mathrm{C}$. Wang et al. 2017). The ubiquitous $\mathrm{NAD}^{+}$is involved in various intracellular metabolic reactions. However, it is released to extracellular space from the dying or dead cells as a DAMP and perceived by the adjacent healthy cells' surface receptor LecRK-I.8. LecRK-1.8 activates the downstream immune signaling accordingly (Mou 2017). Nevertheless, the extracellular lectin domain of LecRK-I.8 binds $\mathrm{NAD}^{+}$with a low concentration dissociation constant; however, much higher concentration is needed to trigger the responses in vivo. It is reasonable to hypothesize that LecRK-I.8 is not the sole or the primary receptor of $\mathrm{eNAD}^{+}$.

\section{Malectin-like-RLKs.}

FER. Malectin-like receptor kinase FER belongs to the $\mathrm{Ca}$ tharantus roseus RLK I-like subfamily. FER is activated by rapid alkalinization factors (RALFs) and mediates extracellular alkalinization in plants. FER is a RALF-regulated scaffold to control plant immunity ( $\mathrm{Li}$ et al. 2015; Stegmann et al. 2017). FER-mediated signaling also functions in various aspects of plant reproduction and root development (Escobar-Restrepo et al. 2007; Haruta et al. 2014, 2018). RALF1 and RALF23, which are FER ligands (Guo et al. 2018; Haruta et al. 2014; Stegmann et al. 2017), are essential for inhibition of primary root cell expansion and retardation of plant immune signaling, respectively. Lorelei-like GPI-anchored protein 1 acts as a coreceptor for FER (Li et al. 2015; Shen et al. 2017).

The fer mutants are less sensitive to PAMPs and more susceptible to bacterial infection than the wild type, suggesting that FER plays crucial roles in pattern-triggered immune responses (Guo et al. 2018; Li et al. 2015). FER is phosphorylated following PAMP treatment and functions as a modulator to promote the association of FLS2/EFR and BAK1 (Shen et al. 2017). FER also hinders signaling of phytohormones abscisic acid and JA; thus, it regulates immunity positively (Guo et al. 2018).
Analogous to elf18, RALFs also regulate PRR complex formation and stimulate JA signaling. Stegmann et al. (2017) found that cotreatment with RALF23, or RALF23 overexpression in fer, represses assembly of ligand-induced receptor kinase complex and PTI immune response (Stegmann et al. 2017).

\section{EGF-like RLK.}

WAK1. There is evidence that EGF-like RLK WAK1 is specifically required for oligogalacturonide (OG) recognition in Arabidopsis (Anderson et al. 2001; Denoux et al. 2008). There are five members of the WAK family in Arabidopsis: namely, WAK1 to WAK5. No phenotype has been seen by inhibition of WAK1, possibly due to the redundancy of these five WAKs (He et al. 1999; Verica and He 2002). WAK2 also mediates immune responses; for instance, through the phosphorylation of MPK6 (Kohorn et al. 2009). OG fragments are released from pectin in the cell wall and proposed as wounding signals (Brutus et al. 2010; Kohorn et al. 2009). All endogenous elicitors such as OGs are characterized as DAMPs, and recognized by WAK1 to form a complex with cytoplasmic plasma membrane-localized kinase-associated protein phosphatase (KAPP) and glycine-rich protein (GRP-3). The complex is localized primarily on the cell wall and with a small portion on the plasma membrane. KAPP and GRP3 negatively regulate the OG-triggered plant immune response (Gramegna et al. 2016; Park et al. 2001).

\section{CORECEPTOR BAK1 AND SERKs}

PAMP perception through PRR activation is linked to RLK coreceptors for PTI-mediated defense. The RLK coreceptor BAK1 is the best-studied and major modulator of PTI (Chinchilla et al. 2007; Roux et al. 2011). EFR (FLS2 or XA21) is associated with the membrane-associated kinase BAK1 (Chinchilla et al. 2007; Schulze et al. 2010; Schwessinger et al. 2011). In addition, there is evidence that the null mutant bakl-4 is affected in early response induced by PEPs in Arabidopsis (Roux et al. 2011). CORE and FLS3 are also associated with BAK1 as part of multiprotein receptors (Hind et al. 2016; L. Wang et al. 2016). Furthermore, BAK1 also functions as an additional coreceptor for PRRs RLP30 and RLP23 (Albert et al. 2015; Zhang et al. 2013). Therefore, the role of BAK1 kinases within PRR complexes is important.

BAK1 is a member of the protein kinase family LRR-RLK II (Boller and Felix 2009). The SERK protein subfamily contains five members in Arabidopsis (SERK1, SERK2, SERK3/BAK1, SERK4 and SERK5). BAK1 is also called SERK3 (Gou et al. 2012). The coreceptor BAK1 plays a pivotal role in diverse signaling pathways (Albrecht et al. 2012).

In addition to PTI signaling, BAK1 also serves as a positive regulator of the BR pathway. BR is the only phytohormone that utilizes cell surface receptors to govern plant growth (Nam and Li 2002), and plays critical roles in almost all stages of plant development ( $\mathrm{Li}$ et al. 2002; Belkhadir et al. 2012). After the BRI1 perceives BRs, transphosphorylation of the receptors is resulted by BRI1-BAK1 heteromerization. Therefore, BAK1 is associated with BR downstream signaling outputs (Li et al. 2002; Wang and Chory 2006).

BAK1 is also involved in cell death and plant immunity by interacting with the calcium-dependent phospholipid-binding protein BONZAI1 (BON1) and BAK1-interacting receptor kinase 1 (BIR1) (Yang and Hua 2004). However, it seems that BAK1 and BIR1 act in distinct pathways, because SOBIR1 is required for autoimmunity of birl, other than bakl bkkl (Liu et al. 2016).

It is null serk1-1 and serk2-1 rather than bakl-4 that are sensitive to elicitors (Heese et al. 2007), suggesting that lower redundancy by other members of the SERK family and BAK1 might 
play a major role in this response (Albrecht et al. 2008; Chinchilla et al. 2007). Roux et al. (2011) found that PRRs also associate with SERK1 and SERK4/BAK1-like 1 which, to some extent, can compensate for a loss of BAK1 in PTI signaling (Roux et al. 2011). Arabidopsis protein phosphatase type 2A (PP2A) plays a critical role in BAK1 activity. PP2A negatively regulates not only BAK1 but also itself (Segonzac et al. 2014).

\section{ECD IS SPECIFIC AND CRITICAL FOR RECOGNITION LIGANDS}

ECDs of RLKs maintain their specific ability in ligand binding, and intracellular domains retain their function in signaling output even when uncoupled. Therefore, the domain swap approach is widely used to study the function of orphan or functionally redundant receptors.

He et al. (2000) demonstrated that perception of the steroid hormone brassinolide (BL) by BRI1 ECD in a chimeric BRI1-XA21 receptor could induce cellular defense signaling controlled by the $\mathrm{XA} 21 \mathrm{KD}$ in rice (He et al. 2000). Later studies revealed that chimeric receptors of FLS2 and EFR, WAK1 and EFR, CEBiP and XA21, AtFLS2 and SI-FLS2, and EFR and Cf-9 could all identify related ligands, to induce a defense response and acquire greater reaction magnitude and recognition spectrum compared with native receptors (Albert and Felix 2010; Albert et al. 2010; Brutus et al. 2010; Kishimoto et al. 2011; Mueller et al. 2012; Wu et al. 2019). These studies also revealed that the original iJM domains in chimeric receptors are necessary for activation (He et al. 2007). Chimeric receptors are useful for understanding signal perception mechanisms such as the determinants for receptor activation and structural basis for ligand interactions.

\section{FLS2 AND EFR TRIGGERED IMMUNE RESPONSE}

FLS2 and EFR receptors switch on the intracellular signals.

It is well known that bacterial flagellin is recognized by the FLS2 receptor, and bacterial elongation factor EF-Tu is recognized by the EFR receptor. EFR and FLS2 are glycosylated transmembrane proteins that need to transit through the secretory pathway in that maturation of EFR/FLS2 in endoplasmic reticulum and Golgi before its destination to plasma membrane (Gómez-Gómez and Boller 2000; Zipfel et al. 2004, 2006).

In the absence of ligand, FLS2 (EFR) and BAK1, an LRRRLK coreceptor, are most likely localized close to the plasma membrane (Boller and Felix 2009; Schwessinger et al. 2011; Wang et al. 2014). BSK1 associates with FLS2 (EFR) and inhibits its activity, and FLS2 (EFR) activity is further suppressed by association with BAK1-interacting receptor kinase 2 (BIR2), a plasma membrane-associated kinase (Schwessinger et al. 2011). BIK1, RLCK, and its homologs (PBS/PBLs AvrPphBsusceptible [PBS]/AvrPphB-susceptible-like proteins [PBLs]) constitutively interact with FLS2 (EFR) in unstimulating cells.

Binding of flg22 results in the release of BAK1 from the BIR2/ BAK1 complex, alteration of FLS2 (EFR) conformation, and triggering of instantaneous FLS2(EFR)-BAK1 heterodimerization (Albrecht et al. 2012; Mbengue et al. 2016; Sun et al. 2013); FLS2 (EFR) and BAK1 kinase are activated to initiate auto- and transphosphorylation. BSK1 and BIK1 are then phosphorylated and released from their receptor complexes (Shen et al. 2017). Activated BIK1 targets the NADPH oxidase RBOHD for phosphorylation; sequentially, active RBOHD catalyzes the production of superoxide, and superoxide is further converted into $\mathrm{H}_{2} \mathrm{O}_{2}$ by peroxidases in the ROS burst. EF-hand motifs in the N-terminal of RBOHD can bind to $\mathrm{Ca}^{2+}$ with high affinity. Those motifs are also required for activation of RBOHD. Meanwhile, RBOHD is phosphorylated by calcium-dependent protein kinases (CDPKs) at CDPK phosphorylation sites for the ROS burst, the conserved signaling output in plant immunity (Kimura et al. 2012). BSK1 is involved in MAPK cascade through phosphorylating MAPK kinase kinase (MAPKKK)5 (Yan et al. 2018). Thus, The PTI signaling pathway is transferred from cell surface receptors to the cell interior via dynamic association or dissociation and transphosphorylation of the downstream proteins of FLS2 (EFR)BAK1 kinase complexes.

It seems that flagellin and EF-Tu trigger the same set of immune responses, although they are recognized by two different receptors. Zipfel et al. (2006) found no additive effect of cotreatment with flg22, elf18, or a combination of both PAMPs. It indicates that signal transduction mediated by FLS2 and EFR receptors converges at a step upstream of MAPK kinases cascade response (Park et al. 2012; Zipfel et al. 2004, 2006). This demonstrates that the kinases promoted by flg 22 and elf 18 represent enzymes belonging to a common pool within cells (Zipfel et al. 2004, 2006) (Fig. 1).

\section{Intracellular downstream signaling events.}

Interactions between ligands and receptors transmit extracellular signals to the entire cell, to initiate intracellular physiological modulations and promote a hierarchical and stereotyped defense response. This ultimately inhibits microbial growth and emits signals to nearby uninfected cells and tissues. Early immune response usually occurs in seconds, minutes, or hours, comprising the accumulation of ROS, changing in ion-fluxes across the plasma membrane, activation of MAPKs, protein phosphorylation, and transcriptional reprogramming. Delayed responses occur within hours to days, including phytohormone biosynthesis, seedling growth inhibition, and callose deposition (Chinchilla et al. 2007; Dodds and Rathjen 2010; Macho and Zipfel 2014; Macho et al. 2014; Monaghan and Zipfel 2012; Zipfel et al. 2006).

ROS burst. Production of ROS is a conserved signaling output following flg22 stimulation. After a lag phase of $2 \mathrm{~min}$, ROS can be quantified by $\mathrm{H}_{2} \mathrm{O}_{2}$-dependent luminescence of luminol (Chinchilla et al. 2007). ROS act as the antibiotic and cell-wall crosslink agents and secondary stress signals to initiate immune responses such as defense gene transcription or stomatal closure (Li et al. 2014; Mersmann et al. 2010; Nathan and Cunningham-Bussel 2013). NADPH oxidase RBOHD is essential for ROS production. Accordingly, a direct link between the activation of the FLS2 (EFR) receptor complex and evaluation of ROS is established (Li et al. 2014).

Activation of heterotrimeric $G$ proteins. Activation of heterotrimeric $G$ proteins is subject to tight regulation and is critical for signal transduction. $\mathrm{G} \alpha$ (extralarge GTP binding protein [XLG]) proteins (namely, XLG1, XLG2, and XLG3) interact with G $\beta$ (Arabidopsis GTP binding protein $\beta$ 1) and G $\gamma$ (Arabidopsis GTP binding protein $\gamma$ unit 1/2) dimers to form heterotrimeric $\mathrm{G}$ proteins. In resting cells, $\mathrm{G}$ protein XLG2 associates with BIK1 to block the proteasome-dependent degradation of BIK1 and stabilize BIK1 protein (Liang et al. 2016; Xue et al. 2020). Activated BIK1 induces $\mathrm{G} \alpha$ protein XLG2 to dissociate from the $\mathrm{G} \beta / \mathrm{G} \gamma$ protein complex. BIK1 also directly phosphorylates the $\mathrm{N}$ terminus of XLG2, which regulates ROS production depending on RBOHD (Dubiella et al. 2013; Liang et al. 2016). Therefore, heterotrimeric $G$ proteins are required for FLS2 (EFR)-mediated immunity.

Activation of MAPKs and CDPKs. It is proposed that the parallel or concerted MAPKs and CDPKs are the potential meeting point for PTI-mediated transcriptional reprogramming downstream of PRRs (Boudsocq et al. 2010; Suarez-Rodriguez et al. 2007). In a recently proposed model, MAPKKK5, as the substrate of BSK1 and BIK1 homolog PBL27 (Yamada et al. 2017; Yamaguchi and Kawasaki 2017; Yan et al. 2018; Zhou et al. 2014), activates MAPK kinase (MKK)4/MKK5 and MPK3/MPK6. Additionally, MAPKKK7 appears to associate with FLS2 and 
attenuate MAPK activation and defense gene expression (Mithoe et al. 2016). MAPK cascades undergo not only cross-regulation between themselves but also cross-talk with other defense pathways. FLS2 induces two MAPK cascades in Arabidopsis (Li et al. 2016). One cascade comprises MAPKKK1, MKK4/MKK5, and MPK3/ MPK6 (Asai et al. 2002; Ichimura et al. 2006; Meng et al. 2013; Suarez-Rodriguez et al. 2007). MAPKKKs or MEKKs are phosphorylated by receptor complexes and subsequently phosphorylate MAPKKs (MAP2Ks, MKKs, or MEKs). Activated MKK4/MKK5 phosphorylates the substrate MAPK, MPK3/ MPK6, to enhance an immune response (Asai et al. 2002; Meng et al. 2013). Another MAPK cascade is composed of MEKK1, MKK1/MKK2, and MPK4, and is similar to the abovementioned MAPK cascade in mechanism (Asai et al. 2002; Ren et al. 2002;

\section{inactive receptor complex}
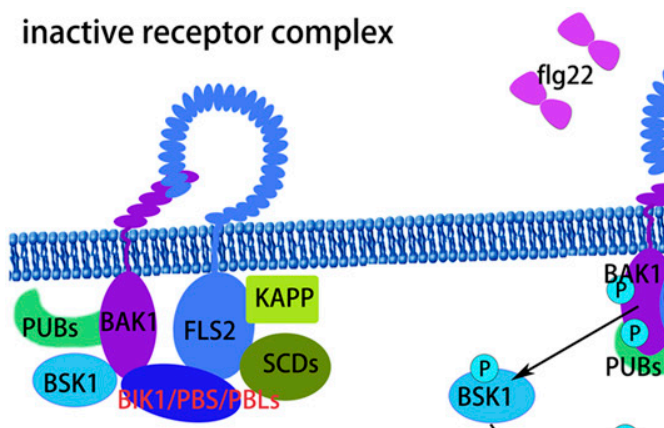

\section{cytoplasm}

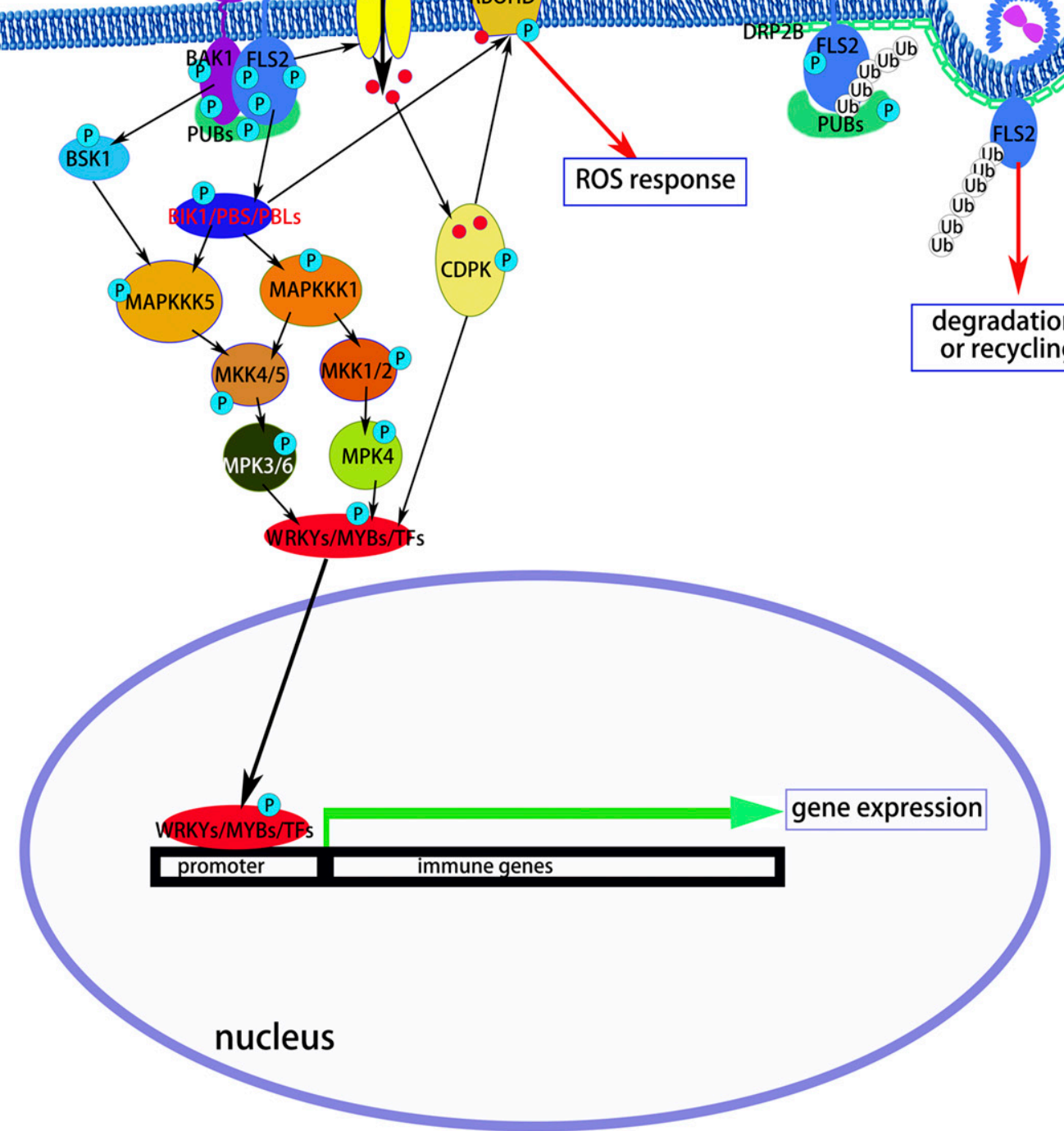

Fig. 1. Model for flg22-FLAGELLIN-SENSITIVE 2 (FLS2) activation signaling pathway. In the absence of ligand flg22, FLS2 is loosely combined with brassinosteroid (BR) receptor-insensitive 1 (BRI1)-associated kinase 1 (BAK1). At the same time, kinase-associated protein phosphatase (KAPP), stomatal cytokinesis defective 1 (SCD1), Botrytis-induced kinase 1 (BIK1)/AvrPphB-susceptible (PBS)/AvrPphB-susceptible-like proteins (PBLs), U-box E3 ubiquitin ligase proteins (PUBs), and BR-signaling kinase 1 (BSK1) are bound to the intracellular domain of receptor complexes. In the presence of ligand flg22, FLS2 recognizes flg22 and its conformation is altered accordingly, making it more suitable for ligand binding. FLS2 triggers the recruitment of coreceptor or adaptor proteins as well as the subsequent phosphorylation. FLS2 heterodimerizes with BAK1 or its homolog BAK1-like 1 (BKK1) prior to auto- and transphosphorylation. Immune signals are delivered into the cell afterward. (i) Cytoplasmic kinases BSK1 and BIK1/PBS/ PBLs are activated by the phosphorylation of FLS2/BAK1 kinases and phosphorylate mitogen-activated protein kinase (MAPK or MPK) kinase kinases (MAPKKKs) and results in MAPK cascade amplification. MPKs subsequently phosphorylate the transcription factors WRKYs/MYBs/TFs. Subsequently, the phosphorylated transcription factors enter the nucleus and bind the promoter region of immune-related genes to improve gene expression. (ii) flg22FLS2/BAK1 activates the calcium channels, leading to the influx of calcium ions. Calcium-dependent protein kinases (CDPKs) are subsequently activated upon increasing intracellular calcium. Transcription factors WRKYs/MYBs/TFs are phosphorylated by CDPKs to initiate gene expression. Phosphorylation of respiratory burst oxidase homolog D (RBOHD) by CDPKs results in reactive oxygen species (ROS) burst. (iii) RBOHD is also activated by the phosphorylation of BIK1/PBS/PBL kinases and causes ROS outbreak. Ubiquitin ligase PUBs are phosphorylated and initiated by active receptor complexes of flg22-FLS2/BAK1. After the polyubiquitination, FLS2 is internalized by flg22-triggered and the synergy of Dynamin-related protein 2B (DRP2B) for receptor degradation or recycling. 
Suarez-Rodriguez et al. 2007). MAPKs phosphorylate some transcription factors such as plant-specific WRKYs and flg22-induced RLK 1, which functions downstream of the MAPK cascade and transfers signals from the receptor complex to cellular response (Asai et al. 2002; Zipfel et al. 2004, 2006). For instance, expression of downstream genes is under regulation of WRKY DNA-BINDING PROTEIN 33 (WRKY33) that is phosphorylated by MPK3/ MPK6 (Mao et al. 2011; Wang et al. 2018).

CDPKs are key signaling modules for plant defense immunity and carry plant-specific protein kinase domains and CaM-like domains that are activated by cytosolic $\mathrm{Ca}^{2+}$ burst. CDPKs are positive regulators of ROS, while ROS regulate immune gene expression and phytohormone accumulation in flg22-triggered immune responses (Boudsocq et al. 2010). Arabidopsis CPK4, CPK5, CPK6, and CPK11 participate in the transmission of innate immunity (Dubiella et al. 2013; Munemasa et al. 2011; Zhu et al. 2007).

Biosynthesis of phytohormones. Phytohormones may act downstream of ligand recognition by receptors. Phytohormones participate in plant defense by monitoring the basal level of signaling components in cells. Several defense-related phytohormones, including SA, ET, and JA, regulate plant immunity and stomatal patterning in response to biotrophic, necrotrophic, and hemibiotrophic pathogens (Bonaventure 2011; Du et al. 2013; Katsir et al. 2008; Tsuda et al. 2009). Although $80 \%$ of PAMPmediated resistance is eliminated in quadruple mutants of JA, ET, phytoalexin-deficient 4 (PAD4), and SA signaling pathways, early PTI-mediated signaling events, comprising MAPK activation and induction of primary immune genes, remain intact. It indicates that SA, JA, ET, and PAD4 control late PTI responses (Tsuda et al. 2009). MAPK cascades are pivotal for the interplay between different hormone pathways. MPK3 and MPK6 possibly operate upstream biosynthesis of SA or JA (Meng et al. 2013; Takahashi et al. 2007), while MKK9-MPK3/6 cascades positively regulate ET signaling (Guan et al. 2015; Jagodzik et al. 2018). WRKY transcription factors are associated with SA and JA pathways. WRKY70, WRKY50, and WRKY51 may be required for positive regulation of the SA pathway and inhibition of JA response, whereas WRKY33 is phosphorylated by MPK3/ 6 , regulating the SA pathway negatively and JA signaling positively (Birkenbihl et al. 2012; Gao et al. 2011; Li et al. 2004). ET biosynthesis triggers transcriptional reprogramming and signal transduction (Tintor et al. 2013). Boutrot et al. (2010) identified significant expression reduction of FLS2 and EFR defenserelated genes in ET-insensitive mutants (Boutrot et al. 2010).

Interaction between SA and ET sets a synergistic effect on PTI, whereas mutual antagonism of ET and JA is demonstrated in immunity (Zhang et al. 2018). The JA and SA signaling pathways show competitive interaction or crosstalk, which might suggest potentially optimized defense against specific attacker (Caarls et al. 2015). It means that dynamic regulation of JA/SA/ ET crosstalk plays an important role in robust PTI signaling networks (Kim et al. 2014).

Ligand-induced endocytosis and degradation. In response to ligand, certain PRRs undergo ligand-induced endocytosis and subsequent intracellular degradation within $1 \mathrm{~h}$. Those PRRs are removed from the plasma membrane and transported through Golgi and multivesicular bodies, so that sustained immune activation is inhibited (Robatzek 2007; Robatzek et al. 2006). Moreover, freshly biosynthesized PRRs recognize PAMPs after $2 \mathrm{~h}$, and also avoid continuous activation of immunity.

Mutants of U-box E3 ubiquitin ligase proteins (PUBs) are less sensitive to PAMPs but more susceptible to bacteria compared with their wild-type equivalents. It indicates that PUBs are required for the plant immune response (Zhang et al. 2017). Lu et al. (2011) found that BAK1 interacts with PUB12/13 to form a complex regardless of PAMPs treatment (Lu et al. 2011;
Sreeramulu et al. 2013); however, ubiquitination was not detected in the absence of ligand. Upon PAMP treatment, BAK1 phosphorylated PUB12/PUB13, which directly ubiquitinates BRI1 KINASE INHIBITOR 1 (BKI1) and results in speeding of BKI1 degradation and negative regulation of salt tolerance (Sreeramulu et al. 2013; Zhang et al. 2017). Degradation-related proteins act as key regulators to overcome pathogen infection. Dynamin-related protein 2B (DRP2B) belongs to the superfamily of high molecular weight GTPases, which contribute to endocytic degradation (Bednarek and Backues 2010; Hong et al. 2003). DRP2B is a negative regulator of ROS production and ligand-induced $\mathrm{Ca}^{2+}$-dependent responses but a positive regulator of robust ligand-induced endocytosis in PAMP signaling (Smith et al. 2014). Similar to DRP2B, stomatal cytokinesis defective 1 (SCD1) and SCD2 are required for clathrin-mediated membrane transport. SCD1 and SCD2 are associated with isolated clathrincoated vesicles and localized in putative sites of endocytosis with clathrin light chains (McMichael et al. 2013).

Increasing data have shed light on immune signaling pathways, though it is well documented that EF-Tu/flg22 sense through proteinaceous EFR/FLS2 at the plasma membrane.

\section{CONCLUSION}

This review mainly is focused on how ligands interact with their receptors and how signals are transmitted to trigger immunity. Despite increasing availability of analyzing technology, it has been highlighted that identification and characterization of PAMPs and DAMPs remain challenging in recent studies. There are still many unknown receptors and ligands waiting to be discovered. Microbial and danger signals can be perceived by distinct ligand-receptor pairs (PRR/PAMP pairs); therefore, PRR complexes are formed and undergo phosphorylation events, or ligand-induced endocytosis, to prime similar cellular immune responses. Activation and attenuation of PRR signaling are critical for plant survival. However, little is known about how structurally similar KDs activate the downstream and how the PRR-regulated upstream pathways converge. The link between PRR complexes and branched signaling activation remains unresolved. It will be interesting to investigate the interaction mechanism between PRRs and PAMPs. Further encouraging discoveries are certainly awaiting us in plant immune studies.

\section{LITERATURE CITED}

Albert, I., Böhm, H., Albert, M., Feiler, C. E., Imkampe, J., Wallmeroth, N., Brancato, C., Raaymakers, T. M., Oome, S., Zhang, H., Krol, E., Grefen, C., Gust, A. A., Chai, J., Hedrich, R., Van den Ackerveken, G., and Nürnberger, T. 2015. An RLP23-SOBIR1-BAK1 complex mediates NLP-triggered immunity. Nat. Plants 1:15140.

Albert, I., Zhang, L., Bemm, H., and Nürnberger, T. 2019. Structurefunction analysis of immune receptor AtRLP23 with its ligand nlp20 and coreceptors AtSOBIR1 and AtBAK1. Mol. Plant-Microbe Interact. 32:1038-1046.

Albert, M., and Felix, G. 2010. Chimeric receptors of the Arabidopsis thaliana pattern recognition receptors EFR and FLS2. Plant Signal. Behav. 5:1430-1432.

Albert, M., Jehle, A. K., Mueller, K., Eisele, C., Lipschis, M., and Felix, G. 2010. Arabidopsis thaliana pattern recognition receptors for bacterial elongation factor Tu and flagellin can be combined to form functional chimeric receptors. J. Biol. Chem. 285:19035-19042.

Albrecht, C., Boutrot, F., Segonzac, C., Schwessinger, B., Gimenez-Ibanez, S., Chinchilla, D., Rathjen, J. P., de Vries, S. C., and Zipfel, C. 2012. Brassinosteroids inhibit pathogen-associated molecular pattern-triggered immune signaling independent of the receptor kinase BAK1. Proc. Natl. Acad. Sci. U.S.A. 109:303-308.

Albrecht, C., Russinova, E., Kemmerling, B., Kwaaitaal, M., and de Vries, S. C. 2008. Arabidopsis SOMATIC EMBRYOGENESIS RECEPTOR KINASE proteins serve brassinosteroid-dependent and -independent signaling pathways. Plant Physiol. 148:611-619. 
Alfano, J. R., and Collmer, A. 2004. Type III secretion system effector proteins: Double agents in bacterial disease and plant defense. Annu. Rev. Phytopathol. 42:385-414.

Amano, Y., Tsubouchi, H., Shinohara, H., Ogawa, M., and Matsubayashi, Y. 2007. Tyrosine-sulfated glycopeptide involved in cellular proliferation and expansion in Arabidopsis. Proc. Natl. Acad. Sci. U.S.A. 104:18333-18338.

Anderson, C. M., Wagner, T. A., Perret, M., He, Z.-H., He, D., and Kohorn, B. D. 2001. WAKs: Cell wall-associated kinases linking the cytoplasm to the extracellular matrix. Plant Mol. Biol. 47:197-206.

Asai, T., Tena, G., Plotnikova, J., Willmann, M. R., Chiu, W. L., GomezGomez, L., Boller, T., Ausubel, F. M., and Sheen, J. 2002. MAP kinase signalling cascade in Arabidopsis innate immunity. Nature 415:977-983.

Austin, M. J., Muskett, P., Kahn, K., Feys, B. J., Jones, J. D., and Parker, J. E. 2002. Regulatory role of SGT1 in early R gene-mediated plant defenses. Science 295:2077-2080.

Bartels, S., Lori, M., Mbengue, M., van Verk, M., Klauser, D., Hander, T., Böni, R., Robatzek, S., and Boller, T. 2013. The family of Peps and their precursors in Arabidopsis: Differential expression and localization but similar induction of pattern-triggered immune responses. J. Exp. Bot. 64:5309-5321.

Bednarek, S. Y., and Backues, S. K. 2010. Plant dynamin-related protein families DRP1 and DRP2 in plant development. Biochem. Soc. Trans. 38:797-806.

Belkhadir, Y., Jaillais, Y., Epple, P., Balsemão-Pires, E., Dangl, J. L., and Chory, J. 2012. Brassinosteroids modulate the efficiency of plant immune responses to microbe-associated molecular patterns. Proc. Natl. Acad. Sci. U.S.A. 109:297-302.

Bi, G., Liebrand, T. W., Bye, R. R., Postma, J., van der Burgh, A. M., Robatzek, S., Xu, X., and Joosten, M. H. 2016. SOBIR1 requires the GxxxG dimerization motif in its transmembrane domain to form constitutive complexes with receptor-like proteins. Mol. Plant Pathol. 17:96-107.

Birkenbihl, R. P., Diezel, C., and Somssich, I. E. 2012. Arabidopsis WRKY33 is a key transcriptional regulator of hormonal and metabolic responses toward Botrytis cinerea infection. Plant Physiol. 159:266-285.

Bojar, D., Martinez, J., Santiago, J., Rybin, V., Bayliss, R., and Hothorn, M. 2014. Crystal structures of the phosphorylated BRI1 kinase domain and implications for brassinosteroid signal initiation. Plant J. 78:31-43.

Boller, T., and Felix, G. 2009. A renaissance of elicitors: Perception of microbe-associated molecular patterns and danger signals by patternrecognition receptors. Annu. Rev. Plant Biol. 60:379-406.

Bonaventure, G. 2011. The Nicotiana attenuata LECTIN RECEPTOR KINASE 1 is involved in the perception of insect feeding. Plant Signal. Behav. 6:2060-2063.

Boudsocq, M., Willmann, M. R., McCormack, M., Lee, H., Shan, L., He, P., Bush, J., Cheng, S. H., and Sheen, J. 2010. Differential innate immune signalling via $\mathrm{Ca}^{2+}$ sensor protein kinases. Nature 464:418-422.

Boutrot, F., Segonzac, C., Chang, K. N., Qiao, H., Ecker, J. R., Zipfel, C., and Rathjen, J. P. 2010. Direct transcriptional control of the Arabidopsis immune receptor FLS2 by the ethylene-dependent transcription factors EIN3 and EIL1. Proc. Natl. Acad. Sci. U.S.A. 107:14502-14507.

Brutus, A., Sicilia, F., Macone, A., Cervone, F., and De Lorenzo, G. 2010. A domain swap approach reveals a role of the plant wall-associated kinase 1 (WAK1) as a receptor of oligogalacturonides. Proc. Natl. Acad. Sci. U.S.A. 107:9452-9457.

Caarls, L., Pieterse, C. M. J., and Van Wees, S. C. M. 2015. How salicylic acid takes transcriptional control over jasmonic acid signaling. Front. Plant Sci. 6:170.

Cai, R., Lewis, J., Yan, S., Liu, H., Clarke, C. R., Campanile, F., Almeida, N. F., Studholme, D. J., Lindeberg, M., Schneider, D., Zaccardelli, M., Setubal, J. C., Morales-Lizcano, N. P., Bernal, A., Coaker, G., Baker, C., Bender, C. L., Leman, S., and Vinatzer, B. A. 2011. The plant pathogen Pseudomonas syringae pv. tomato is genetically monomorphic and under strong selection to evade tomato immunity. PLoS Pathog. 7:e1002130.

Cao, Y., Ding, X., Cai, M., Zhao, J., Lin, Y., Li, X., Xu, C., and Wang, S. 2007. The expression pattern of a rice disease resistance gene xa3/ xa26 is differentially regulated by the genetic backgrounds and developmental stages that influence its function. Genetics 177:523-533.

Cao, Y., Liang, Y., Tanaka, K., Nguyen, C.T., and Stacey, G. 2014. The kinase LYK5 is a major chitin receptor in Arabidopsis and forms a chitin-induced complex with related kinase CERK1. eLife 3:e03766.

Castroverde, C. D., Nazar, R. N., and Robb, J. 2016. Verticillium Ave1 effector induces tomato defense gene expression independent of $\mathrm{Ve} 1$ protein. Plant Signal. Behav. 11:e1245254.

Chen, C. W., Panzeri, D., Yeh, Y. H., Kadota, Y., Huang, P. Y., Tao, C. N., Roux, M., Chien, S. C., Chin, T. C., Chu, P. W., Zipfel, C., and
Zimmerli, L. 2014. The Arabidopsis malectin-like leucine-rich repeat receptor-like kinase IOS1 associates with the pattern recognition receptors FLS2 and EFR and is critical for priming of pattern-triggered immunity. Plant Cell 26:3201-3219.

Chen, D., Cao, Y., Li, H., Kim, D., Ahsan, N., Thelen, J., and Stacey, G. 2017. Extracellular ATP elicits DORN1-mediated RBOHD phosphorylation to regulate stomatal aperture. Nat. Commun. 8:2265.

Chen, X., Chern, M., Canlas, P. E., Ruan, D., Jiang, C., and Ronald, P. C. 2010. An ATPase promotes autophosphorylation of the pattern recognition receptor XA21 and inhibits XA21-mediated immunity. Proc. Natl. Acad. Sci. U.S.A. 107:8029-8034.

Chen, X., Zuo, S., Schwessinger, B., Chern, M., Canlas, P. E., Ruan, D., Zhou, X., Wang, J., Daudi, A., Petzold, C. J., Heazlewood, J. L., and Ronald, P. C. 2014. An XA21-associated kinase (OsSERK2) regulates immunity mediated by the XA21 and XA3 immune receptors. Mol. Plant 7:874-892.

Chinchilla, D., Bauer, Z., Regenass, M., Boller, T., and Felix, G. 2006. The Arabidopsis receptor kinase FLS2 binds flg22 and determines the specificity of flagellin perception. Plant Cell 18:465-476.

Chinchilla, D., Zipfel, C., Robatzek, S., Kemmerling, B., Nürnberger, T., Jones, J. D., Felix, G., and Boller, T. 2007. A flagellin-induced complex of the receptor FLS2 and BAK1 initiates plant defence. Nature 448:497-500.

Choi, J., Tanaka, K., Cao, Y., Qi, Y., Qiu, J., Liang, Y., Lee, S. Y., and Stacey, G. 2014. Identification of a plant receptor for extracellular ATP. Science 343:290-294.

Clarke, C. R., Chinchilla, D., Hind, S. R., Taguchi, F., Miki, R., Ichinose, Y., Martin, G. B., Leman, S., Felix, G., and Vinatzer, B. A. 2013. Allelic variation in two distinct Pseudomonas syringae flagellin epitopes modulates the strength of plant immune responses but not bacterial motility. New Phytol. 200:847-860.

Clarke, C. R., and Vinatzer, B. A. 2017. Characterizing the immune-eliciting activity of putative microbe-associated molecular patterns in tomato. Methods Mol. Biol. 1578:249-261.

Dardick, C., and Ronald, P. 2006. Plant and animal pathogen recognition receptors signal through non-RD kinases. PLoS Pathog. 2:e2.

de Jonge, R., van Esse, H. P., Maruthachalam, K., Bolton, M. D., Santhanam, P., Saber, M. K., Zhang, Z., Usami, T., Lievens, B., Subbarao, K. V., Thomma, B. P. 2012. Tomato immune receptor Ve1 recognizes effector of multiple fungal pathogens uncovered by genome and RNA sequencing. Proc. Natl. Acad. Sci. U.S.A. 109:5110-5115.

De Lorenzo, G., Brutus, A., Savatin, D. V., Sicilia, F., and Cervone, F. 2011. Engineering plant resistance by constructing chimeric receptors that recognize damage-associated molecular patterns (DAMPs). FEBS Lett. 585:1521-1528.

Denoux, C., Galletti, R., Mammarella, N., Gopalan, S., Werck, D., DeLorenzo, G., Ferrari, S., Ausubel, F. M., and Dewdney, J. 2008. Activation of defense response pathways by OGs and Flg22 elicitors in Arabidopsis seedlings. Mol. Plant 1:423-445.

Desaki, Y., Miyata, K., Suzuki, M., Shibuya, N., and Kaku, H. 2018a. Plant immunity and symbiosis signaling mediated by LysM receptors. Innate Immun. 24:92-100.

Desaki, Y., Kouzai, Y., Ninomiya, Y., Iwase, R., Shimizu, Y., Seko, K., Molinaro, A., Minami, E., Shibuya, N., Kaku, H., and Nishizawa, Y. 2018b. OsCERK1 plays a crucial role in the lipopolysaccharide-induced immune response of rice. New Phytol. 217:1042-1049.

Desaki, Y., Takahashi, S., Sato, K., Maeda, K., Matsui, S., Yoshimi, I., Miura, T., Jumonji, J. I., Takeda, J., Yashima, K., Kohari, M., Suenaga, T., Terada, H., Narisawa, T., Shimizu, T., Yumoto, E., Miyamoto, K., Narusaka, M., Narusaka, Y., Kaku, H., and Shibuya, N. 2019. PUB4, a CERK1-interacting ubiquitin ligase, positively regulates MAMP-triggered immunity in Arabidopsis. Plant Cell Physiol. 60:2573-2583.

Dodds, P. N., and Rathjen, J. P. 2010. Plant immunity: Towards an integrated view of plant-pathogen interactions. Nat. Rev. Genet. 11:539-548.

Domazakis, E., Wouters, D., Visser, R. G. F., Kamoun, S., Joosten, M. H. A. J., and Vleeshouwers, V. G. A. A. 2018. The ELR-SOBIR1 complex functions as a two-component receptor-like kinase to mount defense against Phytophthora infestans. Mol. Plant-Microbe Interact. 31:795-802.

Du, J., Verzaux, E., Chaparro-Garcia, A., Bijsterbosch, G., Keizer, L. C., Zhou, J., Liebrand, T. W., Xie, C., Govers, F., Robatzek, S., van der Vossen, E. A., Jacobsen, E., Visser, R. G., Kamoun, S., and Vleeshouwers, V. G. 2015. Elicitin recognition confers enhanced resistance to Phytophthora infestans in potato. Nat. Plants 1:15034.

Du, Y., Tejos, R., Beck, M., Himschoot, E., Li, H., Robatzek, S., Vanneste, S., and Friml, J. 2013. Salicylic acid interferes with 
clathrin-mediated endocytic protein trafficking. Proc. Natl. Acad. Sci. U.S.A. 110:7946-7951.

Dubiella, U., Seybold, H., Durian, G., Komander, E., Lassig, R., Witte, C. P., Schulze, W. X., and Romeis, T. 2013. Calcium-dependent protein kinase/NADPH oxidase activation circuit is required for rapid defense signal propagation. Proc. Natl. Acad. Sci. U.S.A. 110:8744-8749.

Erwig, J., Ghareeb, H., Kopischke, M., Hacke, R., Matei, A., Petutschnig, E., and Lipka, V. 2017. Chitin-induced and CHITIN ELICITOR RECEPTOR KINASE1 (CERK1) phosphorylation-dependent endocytosis of Arabidopsis thaliana LYSIN MOTIF-CONTAINING RECEPTORLIKE KINASE5 (LYK5). New Phytol. 215:382-396.

Escobar-Restrepo, J. M., Huck, N., Kessler, S., Gagliardini, V., Gheyselinck, J., Yang, W. C., and Grossniklaus, U. 2007. The FERONIA receptor-like kinase mediates male-female interactions during pollen tube reception. Science 317:656-660

Faulkner, C., Petutschnig, E., Benitez-Alfonso, Y., Beck, M., Robatzek, S., Lipka, V., and Maule, A. J. 2013. LYM2-dependent chitin perception limits molecular flux via plasmodesmata. Proc. Natl. Acad. Sci. U.S.A. 110:9166-9170.

Felix, G., and Boller, T. 2002. Molecular sensing of bacteria in plants. J. Biol. Chem. 278:6201-6208.

Fliegmann, J., and Felix, G. 2016. Immunity: Flagellin seen from all sides. Nat. Plants 2:16136.

Flury, P., Klauser, D., Schulze, B., Boller, T., and Bartels, S. 2013. The anticipation of danger: Microbe-associated molecular pattern perception enhances AtPep-triggered oxidative burst. Plant Physiol. 161:2023-2035.

Fradin, E. F., Abd-El-Haliem, A., Masini, L., van den Berg, G. C., Joosten, M. H., and Thomma, B. P. 2011. Interfamily transfer of tomato Ve1 mediates Verticillium resistance in Arabidopsis. Plant Physiol. 156:2255-2265

Fuglsang, A. T., Kristensen, A., Cuin, T. A., Schulze, W. X., Persson, J., Thuesen, K. H., Ytting, C. K., Oehlenschlæger, C. B., Mahmood, K., Sondergaard, T. E., Shabala, S., and Palmgren, M. G. 2014. Receptor kinase-mediated control of primary active proton pumping at the plasma membrane. Plant J. 80:951-964.

Furukawa, T., Inagaki, H., Takai, R., Hirai, H., and Che, F.-S. 2014. Two distinct EF-Tu epitopes induce immune responses in rice and Arabidopsis. Mol. Plant-Microbe Interact. 27:113-124.

Gao, M., Wang, X., Wang, D., Xu, F., Ding, X., Zhang, Z., Bi, D., Cheng, Y. T., Chen, S., Li, X., and Zhang, Y. 2009. Regulation of cell death and innate immunity by two receptor-like kinases in Arabidopsis. Cell Host Microbe 6:34-44.

Gao, Q.-M., Venugopal, S., Navarre, D., and Kachroo, A. 2011. Low oleic acid-derived repression of jasmonic acid-inducible defense responses requires the WRKY50 and WRKY51 proteins. Plant Physiol. 155:464-476.

Gómez-Gómez, L., and Boller, T. 2000. FLS2: An LRR receptor-like kinase involved in the perception of the bacterial elicitor flagellin in Arabidopsis. Mol. Cell 5:1003-1011.

Gou, X., Yin, H., He, K., Du, J., Yi, J., Xu, S., Lin, H., Clouse, S. D., and $\mathrm{Li}, \mathrm{J}$. 2012. Genetic evidence for an indispensable role of somatic embryogenesis receptor kinases in brassinosteroid signaling. PLoS Genet. 8:e1002452.

Gramegna, G., Modesti, V., Savatin, D. V., Sicilia, F., Cervone, F., and De Lorenzo, G. 2016. GRP-3 and KAPP, encoding interactors of WAK1, negatively affect defense responses induced by oligogalacturonides and local response to wounding. J. Exp. Bot. 67:1715-1729.

Guan, R., Su, J., Meng, X., Li, S., Liu, Y., Xu, J., and Zhang, S. 2015. Multilayered regulation of ethylene induction plays a positive role in Arabidopsis resistance against Pseudomonas syringae. Plant Physiol. 169:299-312.

Gubaeva, E., Gubaev, A., Melcher, R. L. J., Cord-Landwehr, S., Singh, R., El Gueddari, N. E., and Moerschbacher, B. M. 2018. 'Slipped Sandwich' model for chitin and chitosan perception in Arabidopsis. Mol. Plant-Microbe Interact. 31:1145-1153.

Guo, H., Nolan, T. M., Song, G., Liu, S., Xie, Z., Chen, J., Schnable, P. S., Walley, J. W., and Yin, Y. 2018. FERONIA receptor kinase contributes to plant immunity by suppressing jasmonic acid signaling in Arabidopsis thaliana. Curr. Biol. 28:3316-3324.e6.

Haruta, M., Gaddameedi, V., Burch, H., Fernandez, D., and Sussman, M. R. 2018. Comparison of the effects of a kinase-dead mutation of FERONIA on ovule fertilization and root growth of Arabidopsis. FEBS Lett. 592:2395-2402.

Haruta, M., Sabat, G., Stecker, K., Minkoff, B. B, and Sussman, M. R. 2014. A peptide hormone and its receptor protein kinase regulate plant cell expansion. Science 343:408-411.
Hayafune, M., Berisio, R., Marchetti, R., Silipo, A., Kayama, M., Desaki, Y., Arima, S., Squeglia, F., Ruggiero, A., Tokuyasu, K., Molinaro, A., Kaku, H., and Shibuya, N. 2014. Chitin-induced activation of immune signaling by the rice receptor $\mathrm{CEBiP}$ relies on a unique sandwich-type dimerization. Proc. Natl. Acad. Sci. U.S.A. 111:E404-E413.

Hayashi, F., Smith, K. D., Ozinsky, A., Hawn, T. R., Yi, E. C., Goodlett, D. R., Eng, J. K., Akira, S., Underhill, D. M., and Aderem, A. 2001 The innate immune response to bacterial flagellin is mediated by tolllike receptor 5. Nature 410:1099-1103.

He, P., Shan, L., and Sheen, J. 2007. Elicitation and suppression of microbe-associated molecular pattern-triggered immunity in plant-microbe interactions. Cell. Microbiol. 9:1385-1396.

He, Z., Wang, Z.-Y., Li, J., Zhu, Q., Lamb, C., Ronald, P., and Chory, J. 2000. Perception of brassinosteroids by the extracellular domain of the receptor kinase BRI1. Science 288:2360-2363.

He, Z.-H., Cheeseman, I., He, D., and Kohorn, B. D. 1999. A cluster of five cell wall-associated receptor kinase genes, Wak1-5, are expressed in specific organs of Arabidopsis. Plant Mol. Biol. 39:1189-1196.

Heese, A., Hann, D. R., Gimenez-Ibanez, S., Jones, A. M. E., He, K., Li, J., Schroeder, J. I., Peck, S. C., and Rathjen, J. P. 2007. The receptorlike kinase SERK3/BAK1 is a central regulator of innate immunity in plants. Proc. Natl. Acad. Sci. U.S.A. 104:12217-12222.

Hind, S. R., Strickler, S. R., Boyle, P. C., Dunham, D. M., Bao, Z., O’Doherty, I. M., Baccile, J. A., Hoki, J. S., Viox, E. G., Clarke, C. R., Vinatzer, B. A., Schroeder, F. C., and Martin, G. B. 2016. Tomato receptor FLAGELLIN-SENSING 3 binds flgII-28 and activates the plant immune system. Nat. Plants 2:16128.

Hohmann, U., and Hothorn, M. 2019. Crystal structure of the leucinerich repeat ectodomain of the plant immune receptor kinase SOBIR1. Acta Crystallogr. D Struct. Biol. 75:488-497.

Hok, S., Danchin, E. G. J., Allasia, V., Panabières, F., Attard, A., and Keller, H. 2011. An Arabidopsis (malectin-like) leucine-rich repeat receptor-like kinase contributes to downy mildew disease. Plant Cell Environ. 34:1944-1957.

Hong, Z., Bednarek, S. Y., Blumwald, E., Hwang, I., Jurgens, G., Menzel, D., Osteryoung, K. W., Raikhel, N. V., Shinozaki, K., Tsutsumi, N., and Verma, D. P. 2003. A unified nomenclature for Arabidopsis dynamin-related large GTPases based on homology and possible functions. Plant Mol. Biol. 53:261-265.

Hou, S., Wang, X., Chen, D., Yang, X., Wang, M., Turrà, D., Di Pietro, A., and Zhang, W. 2014. The secreted peptide PIP1 amplifies immunity through receptor-like kinase 7. PLoS Pathog. 10:e1004331.

Huffaker, A., Dafoe, N. J., and Schmelz, E. A. 2011. ZmPep1, an ortho$\log$ of Arabidopsis elicitor peptide 1, regulates maize innate immunity and enhances disease resistance. Plant Physiol. 155:1325-1338.

Huffaker, A., Pearce, G., and Ryan, C. A. 2006. An endogenous peptide signal in Arabidopsis activates components of the innate immune response. Proc. Natl. Acad. Sci. U.S.A. 103:10098-10103.

Huffaker, A., and Ryan, C. A. 2007. Endogenous peptide defense signals in Arabidopsis differentially amplify signaling for the innate immune response. Proc. Natl. Acad. Sci. U.S.A. 104:10732-10736.

Ichimura, K., Casais, C., Peck, S. C., Shinozaki, K., and Shirasu, K. 2006. MEKK1 is required for MPK4 activation and regulates tissuespecific and temperature-dependent cell death in Arabidopsis. J. Biol. Chem. 281:36969-36976.

Igarashi, D., Tsuda, K., and Katagiri, F. 2012. The peptide growth factor, phytosulfokine, attenuates pattern-triggered immunity. Plant J. 71:194204.

Jagodzik, P., Tajdel-Zielinska, M., Ciesla, A., Marczak, M., and Ludwikow, A. 2018. Mitogen-activated protein kinase cascades in plant hormone signaling. Front. Plant Sci. 9:1387.

Jehle, A. K., Fürst, U., Lipschis, M., Albert, M., and Felix, G. 2013. Perception of the novel MAMP eMax from different Xanthomonas species requires the Arabidopsis receptor-like protein ReMAX and the receptor kinase SOBIR. Plant Signal. Behav. 8:e27408.

Jones, D. A., Thomas, C. M., Hammond-Kosack, K. E., Balint-Kurti, P. J., and Jones, J. D. 1994. Isolation of the tomato $C f-9$ gene for resistance to Cladosporium fulvum by transposon tagging. Science 266:789-793.

Joosten, M. H., Vogelsang, R., Cozijnsen, T. J., Verberne, M. C., and De Wit, P. J. 1997. The biotrophic fungus Cladosporium fulvum circumvents $C f$-4-mediated resistance by producing unstable AVR4 elicitors. Plant Cell 9:367-379.

Kaku, H., Nishizawa, Y., Ishii-Minami, N., Akimoto-Tomiyama, C. Dohmae, N., Takio, K., Minami, E., and Shibuya, N. 2006. Plant cells recognize chitin fragments for defense signaling through a plasma membrane receptor. Proc. Natl. Acad. Sci. U.S.A. 103:11086-11091. 
Katsir, L., Schilmiller, A. L., Staswick, P. E., He, S. Y., and Howe, G. A. 2008. COI1 is a critical component of a receptor for jasmonate and the bacterial virulence factor coronatine. Proc. Natl. Acad. Sci. U.S.A. 105:7100-7105.

Kaufmann, C., Motzkus, M., and Sauter, M. 2017. Phosphorylation of the phytosulfokine peptide receptor PSKR1 controls receptor activity. J. Exp. Bot. 68:1411-1423.

Kawaharada, Y., Kelly, S., Nielsen, M. W., Hjuler, C. T., Gysel, K., Muszyński, A., Carlson, R. W., Thygesen, M. B., Sandal, N., Asmussen, M. H., Vinther, M., Andersen, S. U., Krusell, L., Thirup, S., Jensen, K. J., Ronson, C. W., Blaise, M., Radutoiu, S., and Stougaard, J. 2015. Receptor-mediated exopolysaccharide perception controls bacterial infection. Nature 523:308-312.

Kawaharada, Y., Nielsen, M. W., Kelly, S., James, E. K., Andersen, K. R., Rasmussen, S. R., Füchtbauer, W., Madsen, L. H., Heckmann, A. B., Radutoiu, S., and Stougaard, J. 2017. Differential regulation of the Epr3 receptor coordinates membrane-restricted rhizobial colonization of root nodule primordia. Nat. Commun. 8:14534.

Kawchuk, L. M., Hachey, J., Lynch, D. R., Kulcsar, F., van Rooijen, G., Waterer, D. R., Robertson, A., Kokko, E., Byers, R., Howard, R. J., Fischer, R., and Prufer, D. 2001. Tomato Ve disease resistance genes encode cell surface-like receptors. Proc. Natl. Acad. Sci. U.S.A. 98:6511-6515.

Kim, Y., Tsuda, K., Igarashi, D., Hillmer, R. A., Sakakibara, H., Myers, C. L., and Katagiri, F. 2014. Mechanisms underlying robustness and tunability in a plant immune signaling network. Cell Host Microbe 15:84-94.

Kimura, S., Kaya, H., Kawarazaki, T., Hiraoka, G., Senzaki, E., Michikawa, M., and Kuchitsu, K. 2012. Protein phosphorylation is a prerequisite for the $\mathrm{Ca}^{2+}$-dependent activation of Arabidopsis NADPH oxidases and may function as a trigger for the positive feedback regulation of $\mathrm{Ca}^{2+}$ and reactive oxygen species. Biochim. Biophys. Acta 1823:398-405.

Kishimoto, K., Kouzai, Y., Kaku, H., Shibuya, N., Minami, E., and Nishizawa, Y. 2011. Enhancement of MAMP signaling by chimeric receptors improves disease resistance in plants. Plant Signal. Behav. 6:449-451.

Kohorn, B. D., Johansen, S., Shishido, A., Todorova, T., Martinez, R., Defeo, E., and Obregon, P. 2009. Pectin activation of MAP kinase and gene expression is WAK2 dependent. Plant J. 60:974-982.

Kouzai, Y., Mochizuki, S., Nakajima, K., Desaki, Y., Hayafune, M., Miyazaki, H., Yokotani, N., Ozawa, K., Minami, E., Kaku, H., Shibuya, N., and Nishizawa, Y. 2014. Targeted gene disruption of OsCERK1 reveals its indispensable role in chitin perception and involvement in the peptidoglycan response and immunity in rice. Mol. Plant-Microbe Interact. 27:975-982.

Krol, E., Mentzel, T., Chinchilla, D., Boller, T., Felix, G., Kemmerling, B., Postel, S., Arents, M., Jeworutzki, E., Al-Rasheid, K. A. S., Becker, D., and Hedrich, R. 2010. Perception of the Arabidopsis danger signal peptide 1 involves the pattern recognition receptor AtPEPR1 and its close homologue AtPEPR2. J. Biol. Chem. 285:13471-13479.

Kunze, G., Zipfel, C., Robatzek, S., Niehaus, K., Boller, T., and Felix, G. 2004. The $\mathrm{N}$ terminus of bacterial elongation factor $\mathrm{Tu}$ elicits innate immunity in Arabidopsis plants. Plant Cell 16:3496-3507.

Kutschera, A., Dawid, C., Gisch, N., Schmid, C., Raasch, L., Gerster, T., Schäffer, M., Smakowska-Luzan, E., Belkhadir, Y., Vlot, A. C., Chandler, C. E., Schellenberger, R., Schwudke, D., Ernst, R. K., Dorey, S., Hückelhoven, R., Hofmann, T., and Ranf, S. 2019. Bacterial mediumchain 3-hydroxy fatty acid metabolites trigger immunity in Arabidopsis plants. Science 364:178-181.

Lacombe, S., Rougon-Cardoso, A., Sherwood, E., Peeters, N., Dahlbeck, D., van Esse, H. P., Smoker, M., Rallapalli, G., Thomma, B. P., Staskawicz, B., Jones, J. D., and Zipfel, C. 2010. Interfamily transfer of a plant pattern-recognition receptor confers broad-spectrum bacterial resistance. Nat. Biotechnol. 28:365-369.

Ladwig, F., Dahlke, R. I., Stührwohldt, N., Hartmann, J., Harter, K., and Sauter, M. 2015. Phytosulfokine regulates growth in Arabidopsis through a response module at the plasma membrane that includes $\mathrm{CY}$ CLIC NUCLEOTIDE-GATED CHANNEL17, H+-ATPase, and BAK1. Plant Cell 27:1718-1729.

Larkan, N. J., Ma, L., and Borhan, M. H. 2015. The Brassica napus receptor-like protein RLM2 is encoded by a second allele of the LepR3/ Rlm2 blackleg resistance locus. Plant Biotechnol. J. 13:983-992.

Li, B., Meng, X., Shan, L., and He, P. 2016. Transcriptional regulation of pattern-triggered immunity in plants. Cell Host Microbe 19:641-650.

Li, C., Yeh, F.-L., Cheung, A. Y., Duan, Q., Kita, D., Liu, M.-C., Maman, J., Luu, E. J., Wu, B. W., Gates, L., Jalal, M., Kwong, A., Carpenter, H., and Wu, H.-M. 2015. Glycosylphosphatidylinositol- anchored proteins as chaperones and co-receptors for FERONIA receptor kinase signaling in Arabidopsis. eLife 4:e06587.

Li, J., Brader, G., and Palva, E. T. 2004. The WRKY70 transcription factor: A node of convergence for jasmonate-mediated and salicylate-mediated signals in plant defense. Plant Cell 16:319-331.

Li, J., Wen, J., Lease, K. A., Doke, J. T., Tax, F. E., and Walker, J. C. 2002. BAK1, an Arabidopsis LRR receptor-like protein kinase, interacts with BRI1 and modulates brassinosteroid signaling. Cell 110:213-222.

Li, L., Li, M., Yu, L., Zhou, Z., Liang, X., Liu, Z., Cai, G., Gao, L., Zhang, X., Wang, Y., Chen, S., and Zhou, J. M. 2014. The FLS2-associated kinase BIK1 directly phosphorylates the NADPH oxidase RbohD to control plant immunity. Cell Host Microbe 15:329-338.

Liang, X., Ding, P., Lian, K., Wang, J., Ma, M., Li, L., Li, L., Li, M., Zhang, X., Chen, S., Zhang, Y., and Zhou, J. M. 2016. Arabidopsis heterotrimeric $\mathrm{G}$ proteins regulate immunity by directly coupling to the FLS2 receptor. eLife 5:e13568.

Liebrand, T. W. H., van den Berg, G. C. M., Zhang, Z., Smit, P., Cordewener, J. H. G., America, A. H. P., Sklenar, J., Jones, A. M. E., Tameling, W. I. L., Robatzek, S., Thomma, B. P. J., and Joosten, M. H. A. J. 2013. Receptor-like kinase SOBIR1/EVR interacts with receptor-like proteins in plant immunity against fungal infection. Proc. Natl Acad. Sci. U.S.A. 110:10010-10015.

Liebrand, T. W. H., van den Burg, H. A., and Joosten, M. H. A. J. 2014. Two for all: Receptor-associated kinases SOBIR1 and BAK1. Trends Plant Sci. 19:123-132.

Liu, B., Li, J. F., Ao, Y., Li, Z., Liu, J., Feng, D., Qi, K., He, Y., Zeng, L., Wang, J., and Wang, H. B. 2013. OsLYP4 and OsLYP6 play critical roles in rice defense signal transduction. Plant Signal. Behav. 8:e22980.

Liu, T., Liu, Z., Song, C., Hu, Y., Han, Z., She, J., Fan, F., Wang, J., Jin, C., Chang, J., Zhou, J. M., and Chai, J. 2012. Chitin-induced dimerization activates a plant immune receptor. Science 336:1160-1164

Liu, Y., Huang, X., Li, M., He, P., and Zhang, Y. 2016. Loss-of-function of Arabidopsis receptor-like kinase BIR1 activates cell death and defense responses mediated by BAK1 and SOBIR1. New Phytol. 212:637-645

Liu, Z., Wu, Y., Yang, F., Zhang, Y., Chen, S., Xie, Q., Tian, X., and Zhou, J. M. 2013. BIK1 interacts with PEPRs to mediate ethylene-induced immunity. Proc. Natl. Acad. Sci. U.S.A. 110:6205-6210.

Logemann, E., Birkenbihl, R. P., Rawat, V., Schneeberger, K., Schmelzer, E., and Somssich, I. E. 2013. Functional dissection of the PROPEP2 and PROPEP3 promoters reveals the importance of WRKY factors in mediating microbe-associated molecular pattern-induced expression. New Phytol. 198:1165-1177.

Lori, M., van Verk, M. C., Hander, T., Schatowitz, H., Klauser, D., Flury, P., Gehring, C. A., Boller, T., and Bartels, S. 2015. Evolutionary divergence of the plant elicitor peptides (Peps) and their receptors: Interfamily incompatibility of perception but compatibility of downstream signalling. J. Exp. Bot. 66:5315-5325.

Lu, D., Lin, W., Gao, X., Wu, S., Cheng, C., Avila, J., Heese, A. Devarenne, T. P., He, P., and Shan, L. 2011. Direct ubiquitination of pattern recognition receptor FLS2 attenuates plant innate immunity. Science 332:1439-1442.

Lu, D., Wu, S., Gao, X., Zhang, Y., Shan, L., and He, P. 2010. A receptor-like cytoplasmic kinase, BIK1, associates with a flagellin receptor complex to initiate plant innate immunity. Proc. Natl. Acad. Sci. U.S.A. 107:496-501.

Luderer, R., Takken, F. L., de Wit, P. J., and Joosten, M. H. 2002. Cladosporium fulvum overcomes $C f$-2-mediated resistance by producing truncated AVR2 elicitor proteins. Mol. Microbiol. 45:875-884.

Luo, X., Wu, W., Liang, Y., Xu, N., Wang, Z., Zou, H., and Liu, J. 2020. Tyrosine phosphorylation of the lectin receptor-like kinase LORE regulates plant immunity. EMBO J. 39:e102856.

Luu, D. D., Joe, A., Chen, Y., Parys, K., Bahar, O., Pruitt, R., Chan, L. J. G., Petzold, C. J., Long, K., Adamchak, C., Stewart, V., Belkhadir, Y., and Ronald, P. C. 2019. Biosynthesis and secretion of the microbial sulfated peptide RaxX and binding to the rice XA21 immune receptor. Proc. Natl. Acad. Sci. U.S.A. 116:8525-8534.

Ma, Y., Walker, R. K., Zhao, Y., and Berkowitz, G. A. 2012. Linking ligand perception by PEPR pattern recognition receptors to cytosolic $\mathrm{Ca}^{2+}$ elevation and downstream immune signaling in plants. Proc. Natl. Acad. Sci. U.S.A. 109:19852-19857.

Macho, A. P., Schwessinger, B., Ntoukakis, V., Brutus, A., Segonzac, C., Roy, S., Kadota, Y., Oh, M. H., Sklenar, J., Derbyshire, P., LozanoDurán, R., Malinovsky, F. G., Monaghan, J., Menke, F. L., Huber, S. C. He, S. Y., and Zipfel, C. 2014. A bacterial tyrosine phosphatase inhibits plant pattern recognition receptor activation. Science 343:1509-1512. 
Macho, A. P., and Zipfel, C. 2014. Plant PRRs and the activation of innate immune signaling. Mol. Cell 54:263-272.

Maekawa, T., Kufer, T. A., and Schulze-Lefert, P. 2011. NLR functions in plant and animal immune systems: So far and yet so close. Nat. Immunol. 12:817-826.

Mao, G., Meng, X., Liu, Y., Zheng, Z., Chen, Z., and Zhang, S. 2011. Phosphorylation of a WRKY transcription factor by two pathogen-responsive MAPKs drives phytoalexin biosynthesis in Arabidopsis. Plant Cell 23:1639-1653.

Matsubayashi, Y., and Sakagami, Y. 1996. Phytosulfokine, sulfated peptides that induce the proliferation of single mesophyll cells of Asparagus officinalis L. Proc. Natl. Acad. Sci. U.S.A. 93:7623-7627.

Mbengue, M., Bourdais, G., Gervasi, F., Beck, M., Zhou, J., Spallek, T., Bartels, S., Boller, T., Ueda, T., Kuhn, H., and Robatzek, S. 2016. Clathrin-dependent endocytosis is required for immunity mediated by pattern recognition receptor kinases. Proc. Natl. Acad. Sci. U.S.A. 113:11034-11039.

McMichael, C. M., Reynolds, G. D., Koch, L. M., Wang, C., Jiang, N., Nadeau, J., Sack, F. D., Gelderman, M. B., Pan, J., and Bednarek, S. Y. 2013. Mediation of clathrin-dependent trafficking during cytokinesis and cell expansion by Arabidopsis stomatal cytokinesis defective proteins. Plant Cell 25:3910-3925.

Meng, X., Xu, J., He, Y., Yang, K.-Y., Mordorski, B., Liu, Y., and Zhang, S. 2013. Phosphorylation of an ERF transcription factor by Arabidopsis MPK3/MPK6 regulates plant defense gene induction and fungal resistance. Plant Cell 25:1126-1142.

Mersmann, S., Bourdais, G., Rietz, S., and Robatzek, S. 2010. Ethylene signaling regulates accumulation of the FLS2 receptor and is required for the oxidative burst contributing to plant immunity. Plant Physiol. 154:391-400.

Mithoe, S. C., Ludwig, C., Pel, M. J., Cucinotta, M., Casartelli, A., Mbengue, M., Sklenar, J., Derbyshire, P., Robatzek, S., Pieterse, C. M., Aebersold, R., and Menke, F. L. 2016. Attenuation of pattern recognition receptor signaling is mediated by a MAP kinase kinase kinase. EMBO Rep. 17:441-454.

Miya, A., Albert, P., Shinya, T., Desaki, Y., Ichimura, K., Shirasu, K., Narusaka, Y., Kawakami, N., Kaku, H., and Shibuya, N. 2007. CERK1, a LysM receptor kinase, is essential for chitin elicitor signaling in Arabidopsis. Proc. Natl. Acad. Sci. U.S.A. 104:19613-19618.

Miyata, K., Kozaki, T., Kouzai, Y., Ozawa, K., Ishii, K., Asamizu, E., Okabe, Y., Umehara, Y., Miyamoto, A., Kobae, Y., Akiyama, K., Kaku, H., Nishizawa, Y., Shibuya, N., and Nakagawa, T. 2014. The bifunctional plant receptor, OsCERK1, regulates both chitin-triggered immunity and arbuscular mycorrhizal symbiosis in rice. Plant Cell Physiol. 55:1864-1872.

Monaghan, J., and Zipfel, C. 2012. Plant pattern recognition receptor complexes at the plasma membrane. Curr. Opin. Plant Biol. 15:349357

Moroz, N., and Tanaka, K. 2020. FlgII-28 is a major flagellin-derived defense elicitor in potato. Mol. Plant-Microbe Interact. 33:247-255.

Mosher, S., Seybold, H., Rodriguez, P., Stahl, M., Davies, K. A., Dayaratne, S., Morillo, S. A., Wierzba, M., Favery, B., Keller, H., Tax, F. E., and Kemmerling, B. 2013. The tyrosine-sulfated peptide receptors PSKR1 and PSY1R modify the immunity of Arabidopsis to biotrophic and necrotrophic pathogens in an antagonistic manner. Plant J. 73:469-482.

Mott, G. A., Thakur, S., Smakowska, E., Wang, P. W., Belkhadir, Y., Desveaux, D., and Guttman, D. S. 2016. Genomic screens identify a new phytobacterial microbe-associated molecular pattern and the cognate Arabidopsis receptor-like kinase that mediates its immune elicitation. Genome Biol. 17:98-112.

Mou, Z. 2017. Extracellular pyridine nucleotides as immune elicitors in Arabidopsis. Plant Signal. Behav. 12:e1388977.

Mueller, K., Bittel, P., Chinchilla, D., Jehle, A. K., Albert, M., Boller, T., and Felix, G. 2012. Chimeric FLS2 receptors reveal the basis for differential flagellin perception in Arabidopsis and tomato. Plant Cell 24:2213-2224.

Munemasa, S., Hossain, M. A., Nakamura, Y., Mori, I. C., and Murata, Y. 2011. The Arabidopsis calcium-dependent protein kinase, CPK6, functions as a positive regulator of methyl jasmonate signaling in guard cells. Plant Physiol. 155:553-561.

Nam, K. H., and Li, J. 2002. BRI1/BAK1, a receptor kinase pair mediating brassinosteroid signaling. Cell 110:203-212.

Narusaka, Y., Shinya, T., Narusaka, M., Motoyama, N., Shimada, H., Murakami, K., and Shibuya, N. 2013. Presence of LYM2 dependent but CERK1 independent disease resistance in Arabidopsis. Plant Signal. Behav. 8:e25345.
Nathan, C., and Cunningham-Bussel, A. 2013. Beyond oxidative stress: An immunologist's guide to reactive oxygen species. Nat. Rev. Immunol. 13:349-361.

Niehl, A., Wyrsch, I., Boller, T., and Heinlein, M. 2016. Double-stranded RNAs induce a pattern-triggered immune signaling pathway in plants. New Phytol. 211:1008-1019.

Park, A. R., Cho, S. K., Yun, U. J., Jin, M. Y., Lee, S. H., Sachetto-Martins, G., and Park, O. K. 2001. Interaction of the Arabidopsis receptor protein kinase Wak1 with a glycine-rich protein, AtGRP-3. J. Biol. Chem. 276:26688-26693.

Park, C. J., Caddell, D. F., and Ronald, P. C. 2012. Protein phosphorylation in plant immunity: Insights into the regulation of pattern recognition receptor-mediated signaling. Front. Plant Sci. 3:177.

Park, C. J., Peng, Y., Chen, X., Dardick, C., Ruan, D., Bart, R., Canlas, P. E., and Ronald, P. C. 2008. Rice XB15, a protein phosphatase 2C, negatively regulates cell death and XA21-mediated innate immunity. PLoS Biol. 6:e231.

Pearce, G., Yamaguchi, Y., Munske, G., and Ryan, C. A. 2008. Structure-activity studies of AtPep1, a plant peptide signal involved in the innate immune response. Peptides 29:2083-2089.

Peng, K. C., Wang, C. W., Wu, C. H., Huang, C. T., and Liou, R. F. 2015. Tomato SOBIR1/EVR homologs are involved in elicitin perception and plant defense against the oomycete pathogen Phytophthora parasitica. Mol. Plant-Microbe Interact. 28:913-926.

Petutschnig, E. K., Jones, A. M. E., Serazetdinova, L., Lipka, U., and Lipka, V. 2010. The lysin motif receptor-like kinase (LysM-RLK) CERK1 is a major chitin-binding protein in Arabidopsis thaliana and subject to chitin-induced phosphorylation. J. Biol. Chem. 285:2890228911.

Postel, S., Küfner, I., Beuter, C., Mazzotta, S., Schwedt, A., Borlotti, A., Halter, T., Kemmerling, B., and Nürnberger, T. 2010. The multifunctional leucine-rich repeat receptor kinase BAK1 is implicated in Arabidopsis development and immunity. Eur. J. Cell Biol. 89:169-174.

Pruitt, R. N., Schwessinger, B., Joe, A., Thomas, N., Liu, F., Albert, M., Robinson, M. R., Chan, L. J. G., Luu, D. D., Chen, H., Bahar, O., Daudi, A., De Vleesschauwer, D., Caddell, D., Zhang, W., Zhao, X., Li, X., Heazlewood, J. L., Ruan, D., Majumder, D., Chern, M., Kalbacher, H., Midha, S., Patil, P. B., Sonti, R. V., Petzold, C. J., Liu, C. C., Brodbelt, J. S., Felix, G., and Ronald, P. C. 2015. The rice immune receptor XA21 recognizes a tyrosine-sulfated protein from a Gram-negative bacterium. Sci. Adv. 1:e1500245-e1500256.

Radutoiu, S., Madsen, L. H., Madsen, E. B., Felle, H. H., Umehara, Y. Grønlund, M., Sato, S., Nakamura, Y., Tabata, S., Sandal, N., and Stougaard, J. 2003. Plant recognition of symbiotic bacteria requires two LysM receptor-like kinases. Nature 425:585-592.

Ranf, S., Gisch, N., Schäffer, M., Illig, T., Westphal, L., Knirel, Y. A., Sánchez-Carballo, P. M., Zähringer, U., Hückelhoven, R., Lee, J., and Scheel, D. 2015. A lectin S-domain receptor kinase mediates lipopolysaccharide sensing in Arabidopsis thaliana. Nat. Immunol. 16:426-433.

Ren, D., Yang, H., and Zhang, S. 2002. Cell death mediated by MAPK is associated with hydrogen peroxide production in Arabidopsis. J. Biol. Chem. 277:559-565.

Robatzek, S. 2007. Vesicle trafficking in plant immune responses. Cell. Microbiol. 9:1-8.

Robatzek, S., Chinchilla, D., and Boller, T. 2006. Ligand-induced endocytosis of the pattern recognition receptor FLS2 in Arabidopsis. Genes Dev. 20:537-542.

Robatzek, S., and Wirthmueller, L. 2013. Mapping FLS2 function to structure: LRRs, kinase and its working bits. Protoplasma 250:671-681.

Ron, M., and Avni, A. 2004. The receptor for the fungal elicitor ethylene-inducing xylanase is a member of a resistance-like gene family in tomato. Plant Cell 16:1604-1615.

Ronald, P. C. 1997. The molecular basis of disease resistance in rice. Plant Mol. Biol. 35:179-186.

Ross, A., Yamada, K., Hiruma, K., Yamashita-Yamada, M., Lu, X. Takano, Y., Tsuda, K., and Saijo, Y. 2014. The Arabidopsis PEPR pathway couples local and systemic plant immunity. EMBO J. 33:62-75.

Roux, M., Schwessinger, B., Albrecht, C., Chinchilla, D., Jones, A., Holton, N., Malinovsky, F. G., Tör, M., de Vries, S., and Zipfel, C. 2011. The Arabidopsis leucine-rich repeat receptor-like kinases BAK1/ SERK3 and BKK1/SERK4 are required for innate immunity to hemibiotrophic and biotrophic pathogens. Plant Cell 23:2440-2455.

Saur, I. M. L., Kadota, Y., Sklenar, J., Holton, N. J., Smakowska, E., Belkhadir, Y., Zipfel, C., and Rathjen, J. P. 2016. NbCSPR underlies age-dependent immune responses to bacterial cold shock protein in Nicotiana benthamiana. Proc. Natl. Acad. Sci. U.S.A. 113:3389-3394

Schulze, B., Mentzel, T., Jehle, A. K., Mueller, K., Beeler, S., Boller, T., Felix, G., and Chinchilla, D. 2010. Rapid heteromerization and 
phosphorylation of ligand-activated plant transmembrane receptors and their associated kinase BAK1. J. Biol. Chem. 285:9444-9451.

Schwessinger, B., Bahar, O., Thomas, N., Holton, N., Nekrasov, V., Ruan, D., Canlas, P. E., Daudi, A., Petzold, C. J., Singan, V. R., Kuo, R., Chovatia, M., Daum, C., Heazlewood, J. L., Zipfel, C., and Ronald, P. C. 2015. Transgenic expression of the dicotyledonous pattern recognition receptor EFR in rice leads to ligand-dependent activation of defense responses. PLoS Pathog. 11:e1004809.

Schwessinger, B., Roux, M., Kadota, Y., Ntoukakis, V., Sklenar, J., Jones, A., and Zipfel, C. 2011. Phosphorylation-dependent differential regulation of plant growth, cell death, and innate immunity by the regulatory receptor-like kinase BAK1. PLoS Genet. 7:e1002046.

Segonzac, C., Macho, A. P., Sanmartín, M., Ntoukakis, V., Sánchez-Serrano, J. J., and Zipfel, C. 2014. Negative control of BAK1 by protein phosphatase $2 \mathrm{~A}$ during plant innate immunity. EMBO J. 33:2069-2079.

Shang-Guan, K., Wang, M., Htwe, N. M. P. S., Li, P., Li, Y., Qi, F., Zhang, D., Cao, M., Kim, C., Weng, H., Cen, H., Black, I. M., Azadi, P., Carlson, R. W., Stacey, G., and Liang, Y. 2018. Lipopolysaccharides trigger two successive bursts of reactive oxygen species at distinct cellular locations. Plant Physiol. 176:2543-2556.

Sharon, A., Bailey, B. A., McMurtry, J. P., Taylor, R., and Anderson, J. D. 1992. Characteristics of ethylene biosynthesis-inducing xylanase movement in tobacco leaves. Plant Physiol. 100:2059-2065.

Shen, Q., Bourdais, G., Pan, H., Robatzek, S., and Tang, D. 2017. Arabidopsis glycosylphosphatidylinositol-anchored protein LLG1 associates with and modulates FLS2 to regulate innate immunity. Proc. Natl. Acad. Sci. U.S.A. 114:5749-5754.

Shimizu, T., Nakano, T., Takamizawa, D., Desaki, Y., Ishii-Minami, N., Nishizawa, Y., Minami, E., Okada, K., Yamane, H., Kaku, H., and Shibuya, N. 2010. Two LysM receptor molecules, CEBiP and OsCERK1, cooperatively regulate chitin elicitor signaling in rice. Plant J. 64:204-214.

Shinya, T., Motoyama, N., Ikeda, A., Wada, M., Kamiya, K., Hayafune, M., Kaku, H., and Shibuya, N. 2012. Functional characterization of CEBiP and CERK1 homologs in Arabidopsis and rice reveals the presence of different chitin receptor systems in plants. Plant Cell Physiol. 53:1696-1706.

Shiu, S. H., and Bleecker, A. B. 2001. Receptor-like kinases from Arabidopsis form a monophyletic gene family related to animal receptor kinases. Proc. Natl. Acad. Sci. U.S.A. 98:10763-10768.

Shiu, S. H., and Bleecker, A. B. 2003. Expansion of the receptor-like kinase/Pelle gene family and receptor-like proteins in Arabidopsis. Plant Physiol. 132:530-543.

Shpak, E. D., Lakeman, M. B., and Torii, K. U. 2003. Dominant-negative receptor uncovers redundancy in the Arabidopsis ERECTA Leucinerich repeat receptor-like kinase signaling pathway that regulates organ shape. Plant Cell 15:1095-1110.

Shpak, E. D., McAbee, J. M., Pillitteri, L. J., and Torii, K. U. 2005. Stomatal patterning and differentiation by synergistic interactions of receptor kinases. Science 309:290-293.

Smith, J. M., Leslie, M. E., Robinson, S. J., Korasick, D. A., Zhang, T., Backues, S. K., Cornish, P. V., Koo, A. J., Bednarek, S. Y., and Heese, A. 2014. Loss of Arabidopsis thaliana dynamin-related protein 2B reveals separation of innate immune signaling pathways. PLoS Pathog. 10:e1004578.

Song, W. Y., Wang, G. L., Chen, L. L., Kim, H. S., Pi, L. Y., Holsten, T., Gardner, J., Wang, B., Zhai, W. X., Zhu, L. H., Fauquet, C., and Ronald, P. 1995. A receptor kinase-like protein encoded by the rice disease resistance gene, Xa21. Science 270:1804-1806.

Sreekanta, S., Bethke, G., Hatsugai, N., Tsuda, K., Thao, A., Wang, L., Katagiri, F., and Glazebrook, J. 2015. The receptor-like cytoplasmic kinase PCRK1 contributes to pattern-triggered immunity against $\mathrm{Pseu}$ domonas syringae in Arabidopsis thaliana. New Phytol. 207:78-90.

Sreeramulu, S., Mostizky, Y., Sunitha, S., Shani, E., Nahum, H., Salomon, D., Hayun, L. B., Gruetter, C., Rauh, D., Ori, N., and Sessa, G. 2013. BSKs are partially redundant positive regulators of brassinosteroid signaling in Arabidopsis. Plant J. 74:905-919.

Stegmann, M., Monaghan, J., Smakowska-Luzan, E., Rovenich, H., Lehner, A., Holton, N., Belkhadir, Y., and Zipfel, C. 2017. The receptor kinase FER is a RALF-regulated scaffold controlling plant immune signaling. Science 355:287-289.

Suarez-Rodriguez, M. C., Adams-Phillips, L., Liu, Y., Wang, H., Su, S. H., Jester, P. J., Zhang, S., Bent, A. F., and Krysan, P. J. 2007. MEKK1 is required for flg22-induced MPK4 activation in Arabidopsis plants. Plant Physiol. 143:661-669.

Sun, X., Cao, Y., Yang, Z., Xu, C., Li, X., Wang, S., and Zhang, Q. 2004. Xa26, a gene conferring resistance to Xanthomonas oryzae pv. oryzae in rice, encodes an LRR receptor kinase-like protein. Plant J. 37:517-527.
Sun, Y., Li, L., Macho, A. P., Han, Z., Hu, Z., Zipfel, C., Zhou, J. M., and Chai, J. 2013. Structural basis for flg22-induced activation of the Arabidopsis FLS2-BAK1 immune complex. Science 342:624-628.

Takahashi, F., Yoshida, R., Ichimura, K., Mizoguchi, T., Seo, S., Yonezawa, M., Maruyama, K., Yamaguchi-Shinozaki, K., and Shinozaki, K. 2007. The mitogen-activated protein kinase cascade MKK3-MPK6 is an important part of the jasmonate signal transduction pathway in Arabidopsis. Plant Cell 19:805-818.

Tanaka, K., Choi, J., Cao, Y., and Stacey, G. 2014. Extracellular ATP acts as a damage-associated molecular pattern (DAMP) signal in plants. Front. Plant Sci. 5:446.

Tang, J., Han, Z., Sun, Y., Zhang, H., Gong, X., and Chai, J. 2015. Structural basis for recognition of an endogenous peptide by the plant receptor kinase PEPR1. Cell Res. 25:110-120.

Thomas, N. C., Oksenberg, N., Liu, F., Caddell, D., Nalyvayko, A., Nguyen, Y., Schwessinger, B., and Ronald, P. C. 2018. The rice XA21 ectodomain fused to the Arabidopsis EFR cytoplasmic domain confers resistance to Xanthomonas oryzae pv. oryzae. PeerJ 6:e4456.

Tintor, N., Ross, A., Kanehara, K., Yamada, K., Fan, L., Kemmerling, B., Nürnberger, T., Tsuda, K., and Saijo, Y. 2013. Layered pattern receptor signaling via ethylene and endogenous elicitor peptides during Arabidopsis immunity to bacterial infection. Proc. Natl. Acad. Sci. U.S.A. 110:6211-6216.

Torii, K. U., Mitsukawa, N., Oosumi, T., Matsuura, Y., Yokoyama, R., Whittier, R. F., and Komeda, Y. 1996. The Arabidopsis ERECTA gene encodes a putative receptor protein kinase with extracellular leucine-rich repeats. Plant Cell 8:735-746.

Tsuda, K., Sato, M., Stoddard, T., Glazebrook, J., and Katagiri, F. 2009. Network properties of robust immunity in plants. PLoS Genet. 5:e1000772.

Van den Ackerveken, G. F., Van Kan, J. A., and De Wit, P. J. 1992 Molecular analysis of the avirulence gene $a v r 9$ of the fungal tomato pathogen Cladosporium fulvum fully supports the gene-for-gene hypothesis. Plant J. 2:359-366.

van der Burgh, A. M., Postma, J., Robatzek, S., and Joosten, M. H. A. J. 2019. Kinase activity of SOBIR1 and BAK1 is required for immune signalling. Mol. Plant Pathol. 20:410-422.

Verica, J. A., and He, Z. H. 2002. The cell wall-associated kinase (WAK) and WAK-like kinase gene family. Plant Physiol. 129:455-459.

Wan, J., Tanaka, K., Zhang, X. C., Son, G. H., Brechenmacher, L., Nguyen, T. H., and Stacey, G. 2012. LYK4, a lysin motif receptor-like kinase, is important for chitin signaling and plant innate immunity in Arabidopsis. Plant Physiol. 160:396-406.

Wan, J., Zhang, X.-C., Neece, D., Ramonell, K. M., Clough, S., Kim, S. Y., Stacey, M. G., and Stacey, G. 2008. A LysM receptor-like kinase plays a critical role in chitin signaling and fungal resistance in Arabidopsis. Plant Cell 20:471-481.

Wan, W.-L., Zhang, L., Pruitt, R., Zaidem, M., Brugman, R., Ma, X., Krol, E., Perraki, A., Kilian, J., Grossmann, G., Stahl, M., Shan, L., Zipfel, C., van Kan, J. A. L., Hedrich, R., Weigel, D., Gust, A. A., and Nürnberger, T. 2019. Comparing Arabidopsis receptor kinase and receptor proteinmediated immune signaling reveals BIK1-dependent differences. New Phytol. 221:2080-2095.

Wang, C., Zhou, M., Zhang, X., Yao, J., Zhang, Y., and Mou, Z. 2017 A lectin receptor kinase as a potential sensor for extracellular nicotinamide adenine dinucleotide in Arabidopsis thaliana. eLife 6:e25474.

Wang, G. L., Ruan, D. L., Song, W. Y., Sideris, S., Chen, L., Pi, L. Y., Zhang, S., Zhang, Z., Fauquet, C., Gaut, B. S., Whalen, M. C., and Ronald, P. C. 1998. Xa21D encodes a receptor-like molecule with a leucine-rich repeat domain that determines race-specific recognition and is subject to adaptive evolution. Plant Cell 10:765-779.

Wang, J., Li, H., Han, Z., Zhang, H., Wang, T., Lin, G., Chang, J., Yang, W., and Chai, J. 2015. Allosteric receptor activation by the plant peptide hormone phytosulfokine. Nature 525:265-268.

Wang, J., Shi, H., Zhou, L., Peng, C., Liu, D., Zhou, X., Wu, W., Yin, J., Qin, H., Ma, W., He, M., Li, W., Wang, J., Li, S., and Chen, X. 2017. OsBSK1-2, an orthologous of AtBSK1, is involved in rice immunity. Front. Plant Sci. 8:908.

Wang, L., Albert, M., Einig, E., Fürst, U., Krust, D., and Felix, G. 2016. The pattern-recognition receptor CORE of Solanaceae detects bacterial cold-shock protein. Nat. Plants 2:16185.

Wang, X., and Chory, J. 2006. Brassinosteroids regulate dissociation of BKI1, a negative regulator of BRI1 signaling, from the plasma membrane. Science 313:1118-1122.

Wang, Y., Li, Z., Liu, D., Xu, J., Wei, X., Yan, L., Yang, C., Lou, Z. and Shui, W. 2014. Assessment of BAK1 activity in different plant receptor-like kinase complexes by quantitative profiling of phosphorylation patterns. J. Proteomics 108:484-493. 
Wang, Y., Schuck, S., Wu, J., Yang, P., Döring, A. C., Zeier, J., and Tsuda, K. 2018. A MPK3/6-WRKY33-ALD1-Pipecolic Acid Regulatory Loop Contributes to Systemic Acquired Resistance. Plant Cell 30:2480-2494.

Wang, Y.-S., Pi, L.-Y., Chen, X., Chakrabarty, P. K., Jiang, J., De Leon, A. L., Liu, G.-Z., Li, L., Benny, U., Oard, J., Ronald, P. C., and Song, W. Y. 2006. Rice XA21 binding protein 3 is a ubiquitin ligase required for full Xa21-mediated disease resistance. Plant Cell 18:3635-3646.

Wei, Y., Caceres-Moreno, C., Jimenez-Gongora, T., Wang, K., Sang, Y., Lozano-Duran, R., and Macho, A. P. 2018. The Ralstonia solanacearum csp22 peptide, but not flagellin-derived peptides, is perceived by plants from the Solanaceae family. Plant Biotechnol. J. 16:1349-1362.

Willmann, R., Lajunen, H. M., Erbs, G., Newman, M. A., Kolb, D., Tsuda, K., Katagiri, F., Fliegmann, J., Bono, J. J., Cullimore, J. V., Jehle, A. K., Götz, F., Kulik, A., Molinaro, A., Lipka, V., Gust, A. A., and Nürnberger, T. 2011. Arabidopsis lysin-motif proteins LYM1 LYM3 CERK1 mediate bacterial peptidoglycan sensing and immunity to bacterial infection. Proc. Natl. Acad. Sci. U.S.A. 108:19824-19829.

Wu, J., Reca, I. B., Spinelli, F., Lironi, D., De Lorenzo, G., Poltronieri, P., Cervone, F., Joosten, M. H. A. J., Ferrari, S., and Brutus, A. 2019. An EFR-Cf-9 chimera confers enhanced resistance to bacterial pathogens by SOBIR1- and BAK1-dependent recognition of elf18. Mol. Plant Pathol. 20:751-764.

Wu, Y., and Zhou, J. M. 2013. Receptor-like kinases in plant innate immunity. J. Integr. Plant Biol. 55:1271-1286.

Xu, S., Liao, C. J., Jaiswal, N., Lee, S., Yun, D. J., Lee, S. Y., Garvey, M., Kaplan, I., and Mengiste, T. 2018. Tomato PEPR1 ORTHOLOG RECEPTOR-LIKE KINASE1 regulates responses to systemin, necrotrophic fungi, and insect herbivory. Plant Cell 30:2214-2229.

Xue, D. X., Li, C. L., Xie, Z. P., and Staehelin, C. 2019. LYK4 is a component of a tripartite chitin receptor complex in Arabidopsis thaliana. J. Exp. Bot. 70:5507-5516.

Xue, J., Gong, B. Q., Yao, X., Huang, X., and Li, J. F. 2020. BAK1-mediated phosphorylation of canonical $\mathrm{G}$ protein alpha during flagellin signaling in Arabidopsis. J. Integr. Plant Biol. 62:690-701.

Yamada, K., Yamaguchi, K., Yoshimura, S., Terauchi, A., and Kawasaki, T. 2017. Conservation of chitin-induced MAPK signaling pathways in rice and Arabidopsis. Plant Cell Physiol. 58:993-1002.

Yamada, K., Yamashita-Yamada, M., Hirase, T., Fujiwara, T., Tsuda, K., Hiruma, K., and Saijo, Y. 2016. Danger peptide receptor signaling in plants ensures basal immunity upon pathogen-induced depletion of BAK1. EMBO J. 35:46-61.

Yamaguchi, Y., Huffaker, A., Bryan, A. C., Tax, F. E., and Ryan, C. A. 2010. PEPR2 is a second receptor for the Pep1 and Pep2 peptides and contributes to defense responses in Arabidopsis. Plant Cell 22:508-522.

Yamaguchi, K., and Kawasaki, T. 2017. Chitin-triggered MAPK activation and ROS generation in rice suspension-cultured cells. Pages 309-316 in: Plant Pattern Recognition Receptors. Methods in Molecular Biology, vol. 1578. L. Shan and P. He, eds. Humana Press, New York, NY, U.S.A.

Yamaguchi, Y., Pearce, G., and Ryan, C. A. 2006. The cell surface leucine-rich repeat receptor for AtPep1, an endogenous peptide elicitor in Arabidopsis, is functional in transgenic tobacco cells. Proc. Natl. Acad. Sci. U.S.A. 103:10104-10109.

Yan, H., Zhao, Y., Shi, H., Li, J., Wang, Y., and Tang, D. 2018. BRASSINOSTEROID-SIGNALING KINASE1 phosphorylates
MAPKKK5 to regulate immunity in Arabidopsis. Plant Physiol. 176:2991-3002.

Yan, L., Ma, Y., Liu, D., Wei, X., Sun, Y., Chen, X., Zhao, H., Zhou, J., Wang, Z., Shui, W., and Lou, Z. 2012. Structural basis for the impact of phosphorylation on the activation of plant receptor-like kinase BAK1. Cell Res. 22:1304-1308.

Yang, S., and Hua, J. 2004. A haplotype-specific resistance gene regulated by BONZAI1 mediates temperature-dependent growth control in Arabidopsis. Plant Cell 16:1060-1071.

Yeh, Y.-H., Panzeri, D., Kadota, Y., Huang, Y.-C., Huang, P.-Y., Tao, C.-N., Roux, M., Chien, H.-C., Chin, T.-C., Chu, P.-W., Zipfel, C., and Zimmerli, L. 2016. The Arabidopsis malectin-like/LRR-RLK IOS1 is critical for BAK1-dependent and BAK1-independent pattern-triggered immunity. Plant Cell 28:1701-1721.

Yu, Y., and Assmann, S. M. 2018. Inter-relationships between the heterotrimeric G $\beta$ subunit AGB1, the receptor-like kinase FERONIA, and RALF1 in salinity response. Plant Cell Environ. 41:2475-2489.

Zeng, L., Velásquez, A. C., Munkvold, K. R., Zhang, J., and Martin, G. B. 2012. A tomato LysM receptor-like kinase promotes immunity and its kinase activity is inhibited by AvrPtoB. Plant J. 69:92-103.

Zhang, L., Kars, I., Essenstam, B., Liebrand, T. W. H., Wagemakers, L. Elberse, J., Tagkalaki, P., Tjoitang, D., van den Ackerveken, G., and van Kan, J. A. L. 2014. Fungal endopolygalacturonases are recognized as microbe-associated molecular patterns by the Arabidopsis receptorlike protein RESPONSIVENESS TO BOTRYTIS POLYGALACTURONASES1. Plant Physiol. 164:352-364.

Zhang, M., Zhao, J., Li, L., Gao, Y., Zhao, L., Patil, S. B., Fang, J., Zhang, W., Yang, Y., Li, M., and Li, X. 2017. The Arabidopsis U-box E3 ubiquitin ligase PUB30 negatively regulates salt tolerance by facilitating BRI1 kinase inhibitor 1 (BKI1) degradation. Plant Cell Environ. 40:2831-2843.

Zhang, W., Fraiture, M., Kolb, D., Löffelhardt, B., Desaki, Y., Boutrot, F. F., Tör, M., Zipfel, C., Gust, A. A., and Brunner, F. 2013. Arabidopsis receptor-like protein30 and receptor-like kinase suppressor of BIR1-1/EVERSHED mediate innate immunity to necrotrophic fungi. Plant Cell 25:4227-4241.

Zhang, W., Zhao, F., Jiang, L., Chen, C., Wu, L., and Liu, Z. 2018. Different pathogen defense strategies in Arabidopsis: More than pathogen recognition. Cells 7:252.

Zhou, J., Wu, S., Chen, X., Liu, C., Sheen, J., Shan, L., and He, P. 2014. The Pseudomonas syringae effector HopF2 suppresses Arabidopsis immunity by targeting BAK1. Plant J. 77:235-245.

Zhu, S. Y., Yu, X. C., Wang, X. J., Zhao, R., Li, Y., Fan, R. C., Shang, Y., Du, S. Y., Wang, X. F., Wu, F. Q., Xu, Y. H., Zhang, X. Y., and Zhang, D. P. 2007. Two calcium-dependent protein kinases, CPK4 and CPK11, regulate abscisic acid signal transduction in Arabidopsis. Plant Cell 19:3019-3036.

Zipfel, C., Kunze, G., Chinchilla, D., Caniard, A., Jones, J. D., Boller, T., and Felix, G. 2006. Perception of the bacterial PAMP EF-Tu by the receptor EFR restricts Agrobacterium-mediated transformation. Cell 125:749-760.

Zipfel, C., Robatzek, S., Navarro, L., Oakeley, E. J., Jones, J. D., Felix, G., and Boller, T. 2004. Bacterial disease resistance in Arabidopsis through flagellin perception. Nature 428:764-767. 